\title{
Identifying Psychosocial Risks and Protective Measures for Workers' Mental Wellbeing at the Time of COVID-19: A Narrative Review
}

\author{
Lucrezia Ginevra Lulli ${ }^{1,2, *(\mathbb{C})}$, Gabriele Giorgi ${ }^{3}$, Caterina Pandolfi ${ }^{4}$, Giulia Foti $\left.{ }^{4}{ }^{(}\right)$, Georgia Libera Finstad ${ }^{3,4}\left({ }^{(}\right.$, \\ Giulio Arcangeli ${ }^{1}$ and Nicola Mucci ${ }^{1}$ (])
}

check for updates

Citation: Lulli, L.G.; Giorgi, G.; Pandolfi, C.; Foti, G.; Finstad, G.L.; Arcangeli, G.; Mucci, N. Identifying Psychosocial Risks and Protective Measures for Workers' Mental Wellbeing at the Time of COVID-19: A Narrative Review. Sustainability 2021, 13, 13869. https://doi.org/ $10.3390 /$ su132413869

Academic Editor:

Christian Vandenberghe

Received: 19 November 2021 Accepted: 11 December 2021 Published: 15 December 2021

Publisher's Note: MDPI stays neutral with regard to jurisdictional claims in published maps and institutional affiliations.

Copyright: (c) 2021 by the authors. Licensee MDPI, Basel, Switzerland. This article is an open access article distributed under the terms and conditions of the Creative Commons Attribution (CC BY) license (https:/ / creativecommons.org/licenses/by/ $4.0 /)$.
1 Department of Experimental and Clinical Medicine, University of Florence, 50139 Florence, Italy; nicola.mucci@unifi.it (N.M.); giulio.arcangeli@unifi.it (G.A.)

2 Occupational Medicine School, University of Florence, 50139 Florence, Italy

3 Department of Human Sciences, European University of Rome, 00163 Rome, Italy; gabriele.giorgi@unier.it (G.G.); g.liberafinstad@gmail.com (G.L.F.)

4 Business @ Health Laboratory, European University of Rome, 00163 Rome, Italy; cate.pandolfi@gmail.com (C.P.); giuliafoti.98@gmail.com (G.F.)

* Correspondence: lucreziaginevra.lulli@unifi.it

\begin{abstract}
The spread of the SARS-CoV-2 virus has caused crucial changes in the workplace. Almost two years after the start of the COVID-19 era, new and old psychosocial risks in the workplace threaten workers' mental wellbeing and represent an occupational health challenge. The aim of this review is to identify the most relevant psychosocial factors, negative or protective, contributing to occupational stress during the current pandemic. A literature search was conducted in PubMed, EMBASE, Cochrane Library, Web of Science, Google Scholar and PsycINFO and a total of 51 articles were deemed suitable for inclusion in the review. Analysis of the retrieved articles revealed five main topics related to psychosocial wellbeing in the workplace: 1 . Support from colleagues and organizations; 2 . Home-work interface and balance; 3 . Changes in workload and work demand; 4. Job competence and appropriate training; 5. Job insecurity and financial stress. All five themes were associated with occupational stress and poor mental outcomes, like anxiety, depression, and burnout symptoms. Peer and organizational support seem to have a major impact on workers' mental wellbeing. Recognizing these factors and projecting interventions that mitigate their effects or boost their efficacy is a fundamental step towards dealing with COVID-19 in the workplace, or any such future emergencies.
\end{abstract}

Keywords: COVID-19 pandemic; worker's mental health; occupational stress; occupational safety and health; psychosocial risks; social support; work-home balance; training; job insecurity; workload

\section{Introduction}

The world of work has been profoundly affected by the global virus pandemic. Workers have been forced to change their habits and lifestyle both at an individual and organizational level. Work arrangements and conditions have changed considerably, raising new challenges for the health and wellbeing of workers, whether in the frontline, in essential services, working from home, or having lost their businesses and jobs. The effects of COVID-19 on the mental health of workers have been widely addressed [1-3], especially for healthcare workers (HCWs). The shortage of personal protective equipment (PPE), and the stigmatization of those working in direct contact with the infected, contributed towards the poor mental outcomes of HCWs involved in the sanitary emergency, particularly at the beginning of the pandemic [4,5]. Anxiety, depression, burnout, post-traumatic syndrome disorder (PTSD) and overall poor mental outcomes have been identified in HCWs dealing with the emergency [1,6,7]. For instance, poor workplace infection control put HCWs, especially those on the frontline, at the risk of being infected and bringing the contagion 
home to their family $[8,9]$, causing dramatic psychological distress, especially in the first waves of contagion. In the following phases of the pandemic, the reorganization of the resources and the adjustment of the global market to new medical supply needs, strongly reduced the impact of the PPE impairment on HCWs. Education and awareness within the general public also contributed to a reduction in the aforementioned perception of HCWs. In other economic sectors, the economic crisis and the general uncertainty about the future deeply affected the psychological wellbeing of workers. Those who did not lose their job faced tremendous organizational changes, among which remote working played a big role. After almost two years since the beginning of the COVID-19 era, new and old psychosocial risks in the workplace threaten the mental wellbeing of workers and represent a challenge in Occupational Health. If not appropriately assessed and managed, psychosocial risks may increase stress levels and lead to physical and mental health problems. The ILO defined psychosocial factors in terms of "interactions between and among work environment, job content, organizational conditions and workers' capacities, needs, culture, personal extrajob considerations that may, through perceptions and experience, influence health, work performance and job satisfaction". Psychological responses to occupational stress may include low mood, low motivation, exhaustion, anxiety, depression, burnout and suicidal thoughts [10]. At the same time, even the loss of a job or the dramatic reduction in available work represent a major cause of stress among workers [11]: the social and economic impact of the pandemic was evident from the beginning when the global economy collapsed and millions of people lost their jobs [12-14]. The aim of this review is to identify the relevant work-related psychosocial factors, either negative or protective, during the ongoing COVID-19 pandemic which contribute to occupational stress. The National Institute for Occupational Safety and Health (NIOSH) defines work-related stress as a series of 'harmful physical and emotional reactions that occur when job demands are not commensurate with the worker's abilities, resources or needs'. Work-related stress is determined by work organization, work design and labor relations and occurs when the demands of the job do not match or exceed the capabilities, resources, or needs of the worker, or when the knowledge or abilities of an individual worker or group needed to cope are not matched with the expectations of the organizational culture of an enterprise. In this review we aim to identify the main aspect of work during the pandemic that causes poor mental outcomes of workers or, alternatively, to identify those aspects that can be protective towards stressful and harming working situations, such as those experienced by HCWs on the frontline. Identifying these aspects has a value not only in this precise historical moment, but also in providing us with a better understanding of the psychosocial processes at work during an emergency, which in turn provides preparedness for the critical situations that companies and governments may face in the future [15].

\section{Materials and Methods}

\subsection{Literature Research, Selection and Data Extraction}

A literature search was performed using PubMed, EMBASE, Cochrane Library, Web of Science, Google Scholar and PsycINFO up to April 30th 2021. The search strategy used three main concepts: occupational stress and its several dimensions; "COVID"; and keywords linked to psychological wellbeing and mental health. In particular, the search string for PubMed was the following: ("OCCUPATIONAL STRESS" OR "JOB RELATED STRESS" OR "WORK RELATED STRESS" OR WORKPLACE) AND (COVID) AND (DEPRESSION OR ANXIETY OR "MENTAL HEALTH" OR "PSYCHOLOGICAL HEALTH" OR "PSYCHOLOGICAL WELLBEING" OR PTSD OR "BURNOUT SYNDROME" OR "JOB DEMAND" OR "JOB CONTROL" OR “TECHNOSTRESS" OR "HOME-WORK INTERFACE" OR "SOCIAL SUPPORT" OR "ECONOMIC STRESS"). The same keywords were used for the literature search in the other databases considered. Additionally, a manual search was performed in the bibliography of the most significant papers. The papers were selected based on the following PICO schemes:

Population: working population; 
Intervention: occupational psychosocial stress factors related to COVID crisis/pandemic; Comparison: not considered;

Outcome: negative psychological outcomes (e.g., depression, anxiety, mental stress).

Two independent reviewers read titles and abstracts of the reports identified by the search strategy and made a first screening; subsequently a further selection was made analyzing the full text of the articles. The judgement about the inclusion of each paper was performed separately by the investigators; disagreements were solved by discussing with a third reviewer. Data were extracted by two reviewers and inserted in a spreadsheet, including country of provenience of the study, type of job considered, scale and tools administered to the sample. Each paper was labelled with one or more main topics related to psychosocial factors at work and the main mental outcomes were identified.

\subsection{Inclusion Criteria}

We included in this review only articles that provide an insight into specific psychosocial occupational stress issues and described workplace characteristics that may be related to job stress and negative psychological outcomes. Moreover, the articles selected contain psychological negative outcomes such as depression or anxiety symptoms, or work-related stress outcomes such as emotional exhaustion or job satisfaction. We included in the review only original articles while previous relevant review articles are discussed in the Introduction and Discussion paragraph.

\subsection{Exclusion Criteria}

Reports of less academic significance, editorial articles, letters to the editors, not peer reviewed articles, individual contributions and purely descriptive studies published in scientific conferences, without any quantitative and qualitative inferences were excluded from this review. Moreover, we excluded all the articles describing workers mental issues during the COVID pandemic without any insight into the workplace characteristics and job stress dimension. Finally, we excluded articles referring exclusively to the lack of PPE or impaired safety measures at work as the only workplace dimension analyzed, since the literature has widely proved the negative impact of this dimension on workers mental health.

\section{Results}

The literature search yielded a total of 3159 results: 392 from Pubmed; 42 from EMBASE; 192 from Web of Science; 11 from Cochrane Library; 82 from PsycINFO; and 2440 from Google Scholar. After a first screening by title and abstract, the subsequent reading of the full texts and the removal of duplicates, a total of 51 papers were deemed suitable for inclusion in the review, according to the inclusion and exclusion criteria. The selection process is described in Figure 1. The selected papers are reported in Appendix A Table A1. 


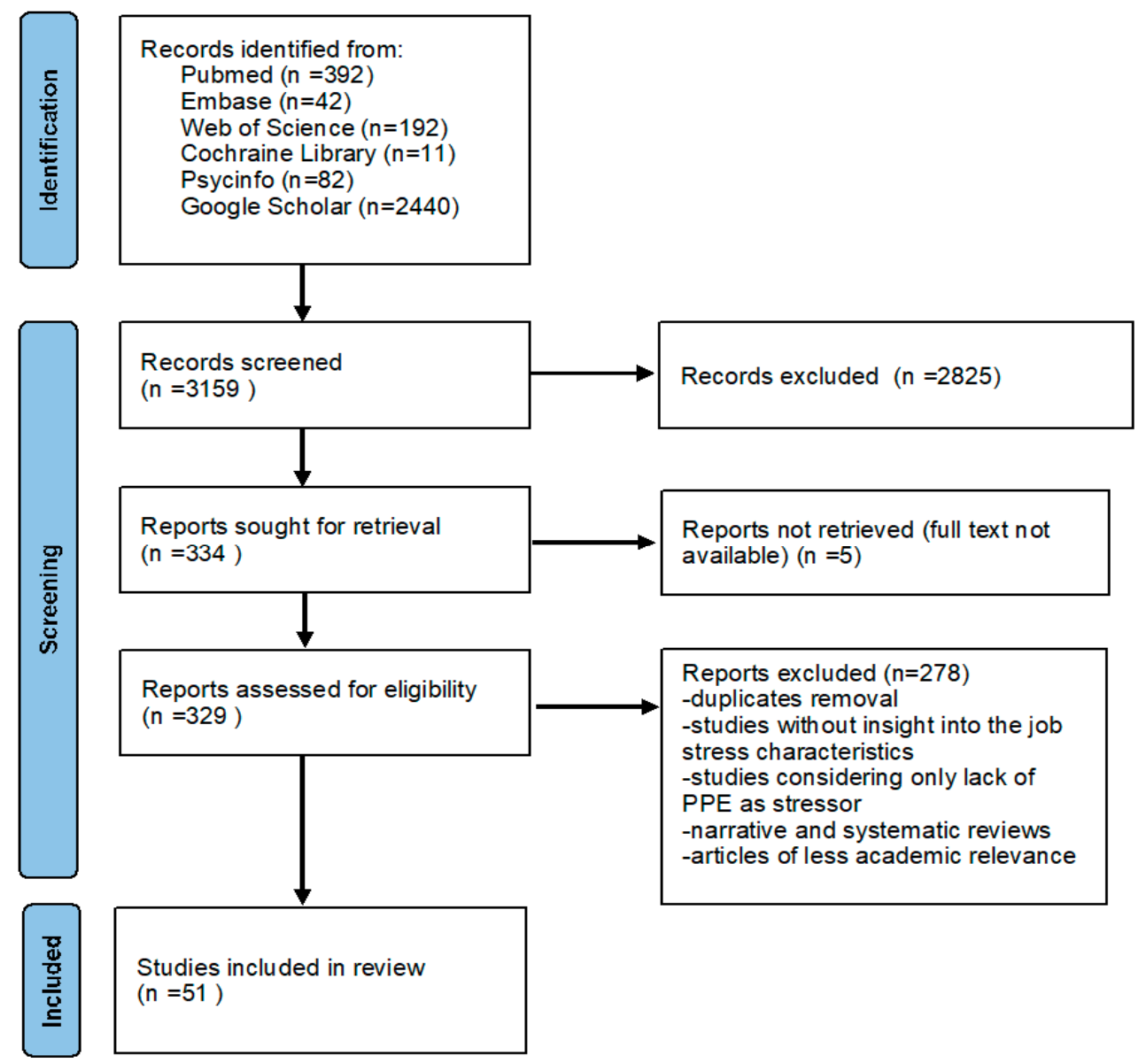

Figure 1. Flow diagram of the literature search and article selection (adapted from PRISMA 2020 guidelines for systematic reviews) [16].

A total of $96 \%$ of the papers selected (49/51) were cross sectional studies, and only two studies showed a longitudinal design. Online self-administered surveys were the most frequent tools used to test the sample. Several psychological dimensions were analyzed. Anxiety was mainly tested with the General Anxiety Disorder Scale (GAD-7), depression with the 9-item Patient Health Questionnaire (PHQ-9) or the Goldberg Anxiety and Depression Scale (GADS), post traumatic syndrome symptoms with the 22-item Impact of Event Scale-Revised (IES-R), and burnout with the Maslach Burnout Inventory (MBI) scale. Often ad hoc questionnaires were developed for some studies; For other studies a qualitative approach with interviews and open questions was adopted.

Regarding workplace aspects, ad hoc questionnaires were generally developed and used by the authors. Validated questionnaires used were the Perceived Social Support Questionnaire (PSSQ) and the Perceived Organizational Support (POS) questionnaire, the Effort-Reward Imbalance questionnaire (ERI), the Colquitt Scale for organizational justice, the Utrecht Work Engagement Scale (UWES) for job satisfaction. Six studies adopted a qualitative approach administering free text questionnaires.

Regarding the geographical provenance of the studies included, European countries were the most represented (21/51, 41.6\%), followed by North America (9/51, 17.6\%) and China $(7 / 51,13.7 \%)$. A total of $38(74.5 \%)$ studies tested healthcare workers of various professions, such as physicians from various specialty backgrounds, nurses, hospital staff, medical assistants, and radiology technicians employed directly or not in the assistance of COVID patients. A further 23 studies (25.5\%) explored work-related stress in non-healthcare workers, employed in several sectors, mostly referring to the homeworking population. 
The analysis of the articles retrieved evidenced five major topics related to psychosocial aspects in the workplace during the COVID-19 pandemic:

1. Support from peers and organizations;

2. Home-work interface and balance;

3. Changes in workload and job demand;

4. Work competence and adequate training;

5. Job insecurity and financial stress.

The results for each topic are reported in the following paragraphs. A summary of the content of each article is included in Table 1 and an overall summary of the findings is presented in Table 1.

Table 1. Summary of main findings and implications.

\begin{tabular}{|c|c|c|}
\hline & Major Findings & Implications \\
\hline $\begin{array}{l}\text { Support from } \\
\text { peers and } \\
\text { organizations }\end{array}$ & $\begin{array}{l}\text {-Most recurrent topic related to } \\
\text { workers mental wellbeing in } \\
\text { pandemics; } \\
\text {-it protects mental health; } \\
\text {-it prevents depression, anxiety and } \\
\text { burnout among workers; } \\
\text {-it has a human and organizational } \\
\text { dimension }\end{array}$ & $\begin{array}{l}\text {-Peer support, communication and } \\
\text { team building training programs } \\
\text { are needed, especially in healthcare } \\
\text { settings; } \\
\text {-organizational changes can } \\
\text { mitigate the impact of the } \\
\text { emergency on workers; } \\
\text {-clear and effective communication } \\
\text { between colleagues and supervisors } \\
\text { is a key factor in preventing poor } \\
\text { mental outcomes. }\end{array}$ \\
\hline $\begin{array}{c}\text { Home-work } \\
\text { interface and } \\
\text { balance }\end{array}$ & $\begin{array}{l}\text {-This is affected by long working } \\
\text { schedules in HCWs } \\
\text { and by the fear of bringing } \\
\text { contagion home } \\
\text {-It implies difficulty in maintaining } \\
\text { work time and home time as } \\
\text { separate for remote workers }\end{array}$ & $\begin{array}{c}\text {-Educating employees and } \\
\text { supervisors in making clear } \\
\text { distinction between free time and } \\
\text { work time } \\
\text {-Government and organizational } \\
\text { measures to support family care can } \\
\text { support workers and protect their } \\
\text { mental health }\end{array}$ \\
\hline $\begin{array}{l}\text { Changes in } \\
\text { workload }\end{array}$ & $\begin{array}{l}\text {-In HCWs, augmented workloads } \\
\text { causes anxiety, depression and } \\
\text { burnout symptoms; } \\
\text {-reduced workloads is associated } \\
\text { with loss of economic status and } \\
\text { subsequent poor mental outcomes; } \\
\text {-for remote workers, it can be } \\
\text { configured as technostress and } \\
\text { threatens home-work balance. }\end{array}$ & $\begin{array}{l}\text {-Providing adequate resting time is } \\
\text { crucial not only for workers' health } \\
\text { but also for patients' safety; } \\
\text {-balancing job demands and } \\
\text { requests with the physical and } \\
\text { psychological resources of workers } \\
\text { is mandatory in every working } \\
\text { environment }\end{array}$ \\
\hline $\begin{array}{l}\text { Work competence } \\
\text { and adequate } \\
\text { training }\end{array}$ & $\begin{array}{l}\text {-This is a major source of stress for } \\
\text { HCWs; } \\
\text {-the fear of making mistakes is } \\
\text { enhanced by the lack of general } \\
\text { protocols to treat COVID; } \\
\text {-the feeling of being pushed beyond } \\
\text { training contributes to the } \\
\text { development of burnout symptoms } \\
\text { especially in young HCWs. }\end{array}$ & $\begin{array}{c}\text {-Healthcare organizations must } \\
\text { provide adequate training } \\
\text { programs, especially when a } \\
\text { worker is redeployed from one } \\
\text { department to another; } \\
\text {-supervisors should understand } \\
\text { when workers are pushed beyond } \\
\text { training } \\
\text {-protocols for the management of } \\
\text { COVID patients and scientific data } \\
\text { sharing are a relevant resource. }\end{array}$ \\
\hline
\end{tabular}


Table 1. Cont.

\begin{tabular}{|c|c|c|}
\hline & Major Findings & Implications \\
\hline $\begin{array}{l}\text { Job insecurity and } \\
\text { financial stress }\end{array}$ & $\begin{array}{l}\text {-The economic crisis linked to the } \\
\text { sanitary emergency meant several } \\
\text { categories of workers were } \\
\text { uncertain of the future; } \\
\text {-the job insecurity and the } \\
\text { consequent financial stress causes } \\
\text { burnout, anxiety and depression } \\
\text { symptoms; } \\
\text {-this also involved HCWs with a } \\
\text { reduction in patient volume. }\end{array}$ & $\begin{array}{l}\text {-Government measures aimed at } \\
\text { sustaining certain working } \\
\text { categories can have an important } \\
\text { impact on mental status of workers; } \\
\text {-when possible, companies should } \\
\text { provide job stabilization and } \\
\text { economic support to workers }\end{array}$ \\
\hline
\end{tabular}

\subsection{Support from Peers and Organization}

A total of 27 studies (53\%) highlighting the importance of support from peers and organizations during the pandemic were included in this review. The selected articles involved different professionals (healthcare workers, employees, security workforce, remote workers, etc.). For most cases, cross-sectional studies were conducted and validated scales, and ad hoc questionnaires and interviews were administered. Depression and anxiety were found to be two psychological dimensions associated with low peer and organizational support [17-23]. An international, cross-sectional study conducted in 41 countries showed that workplace factors, and in particular training for redeployed staff and the provision of wellbeing and mental health support, have a significant negative association with depressive symptoms in workers [17]. Particularly for nurses, low levels of social support and organizational support predicted COVID-19 anxiety [19]. Similarly, reduced social support and difficulties in cooperation between co-workers [20], especially in hospital settings, were associated with high levels of occupational stress [22,24-30]. Moreover, supervisors' support helps employees in dealing with job uncertainties [31] and for essential workers, recognition of the value of their work plays a huge role [32-34]. In several studies, an association between lack of support and burnout syndrome has also been reported [32,35-39]. Perceived organizational support moderated the relationship between the degree of exposure to risk and stress: the relationship appeared weaker when organizational support was perceived as high and the relationship was depicted as stronger when a low level of organizational support was present [38]. Furthermore, organizational and peer support is fundamental in dealing with workplace violence [21]. The support of colleagues helps to control negative emotional reactions in home workers [40]. A supportive environment is protective towards the risk of moral injury for HCWs [41], who are also at risk of post-traumatic syndrome disorder (PTSD). Perceived organizational support, indeed, had a significant indirect effect on PTSD symptoms through the mediation of problem-focused coping strategies and self-efficacy [42].

\subsection{Home-Work Interface and Balance}

A total of 11 studies (22\%) that treat this issue were included in the review. The studies involved healthcare workers and remote workers and explored this dimension through quantitative and qualitative surveys. During the pandemic, home-work interface has become more challenging for workers from different settings, as the effect of the pandemic on job organization threatened to negatively affect the balance between family and work. People working from home during the first lockdown periods experienced less perceived wellbeing than those who remained in their usual workplace [43]. Home workers experienced distractions in the domestic environment [44], however overall working from home had a positive impact on work life [45]. Instead, for HCWs home-work interface was found as a cause of stress and also contributed to the development of burnout symptoms [46,47]. Major concerns included childcare [22,46,48,49], household activities and the relationships with family and friends [50,51]. During this time of emergency HCWs experienced a 
significantly lower work-family balance due to long working hours without appropriate rest [52], which was particularly challenging for women as they tended to be more involved in family care [49]. Moreover, the fear of bringing contagion home to family members was a common issue contributing to occupational stress, anxiety and depression symptoms in HCWs [53].

\subsection{Changes in Workload and Job Demand}

A total of 22 studies (43\%) included in the review considered changes in workload and job demand as a risk factor for workers to develop stress, depression, anxiety and burnout symptoms. The papers selected were cross sectional, original research and descriptive studies using validated and not validated questionnaires, with quantitative and qualitative approach. In particular the articles explored this issue mostly in healthcare workers (nurses, surgeons, medical assistants, etc.) but poor mental outcomes were also attested in nonhealthcare workers. A change in workload during the COVID-19 outbreak (increased, unchanged, decreased or temporary off) is a recurring theme in the studies. For HCWs this is mostly a heavier workload, while for other professionals the negative mental outcomes are often associated with a decrease in their workload [45]. Anxiety, depression and stress were all psychological dimensions positively related to augmented workload and job demand in terms of longer working hours, intensity and efforts [18,20,25,51,54-59]. Workload increased dramatically for workers who reported, suspected, or confirmed SARSCoV-2 cases among their colleagues $[60,61]$ and this plays a crucial role in the dimension of work-life balance [53,62]. Workers with too few rest breaks had more anxiety as they were exhausted, had difficulty meeting their basic needs and were constantly exposed to workplace stressors $[48,63,64]$. Burnout symptoms were also associated with the increase in workload for healthcare and non-healthcare workers $[36,39,65]$. Also, the perception of workload is connected with the overall work environment and to mental workload [39,52]. For physicians, the change in workload also affected the perception of job role, determining high levels of stress [50]. Another relevant aspect was the sudden and massive adoption of remote work, which contributed to the higher workload experienced by some workers. For remote workers, behavioral stress was positively associated with workload, in terms of heavy remote working and use of technologies [57]. For HCWs, telehealth, tele-conferences and working remotely were mostly positive experiences, however the demarcation line between work and home was often less defined [22]. Conversely, it was found that frontline doctors experienced high levels of work-related stress in managing computer work/electronic medical records [48].

\subsection{Work Competence and Adequate Training}

A total of 11 studies among the 51 selected (22\%) underlined the relevance of the dimensions "adequate training/appropriate work competences" for the occurrence of stress and poor mental health in the workplace during the COVID-19 pandemic. All the articles regarding this theme tested healthcare workers belonging to several professions (nurses, physicians, medical assistants, etc.). The studies selected were cross sectional and used validated and not validated questionnaires or qualitative approaches through interviews to assess the dimensions considered in the sample. Anxiety, depression and stress were all psychological dimensions associated with the feeling of inappropriate work competence and the lack of adequate training [58]. At the same time, work impairment was negatively influenced by anxiety and depression [66]. Factors related to poor training correlated to more frequent depressive and anxiety symptoms, including having been redeployed without training or with unsatisfactory training $[17,22,53,55]$. Workplace preparation and communication were identified as controllable and modifiable factors in the workplace, which can be related to psychiatric symptoms [55]. Performance at work, fear of making mistakes and uncertainty about how to act properly were factors associated with psychological distress [25,60] as well as disinformation about COVID-19 [48]. Finally, 
the feeling of being pushed beyond training was found to be a factor in the development of burnout symptoms [47].

\subsection{Job Insecurity and Financial Stress}

Six studies (12\%) identified job insecurity as well as financial issues as being major stressors during the pandemic for workers. These two dimensions related to the pandemic seem to play a role in the development of stress and can determine poor mental health outcomes. Three studies, two from USA and one from Germany, found this aspect in healthcare workers, nurses and physicians, while three studies, two from Spain and one from Canada, provide insights into the psychological conditions of hotel employees, fashion retailing workers and workers in general, respectively. Two studies about HCWs used a qualitative approach to test their sample. Despite the sanitary emergency requiring extraordinary efforts from healthcare workers, even this category experienced forms of stress related to the uncertainty about the future [65] and concerns about the financial situation related to reduced patient volumes $[48,49]$. Physicians reported furloughs and pay cuts and expressed frustration at assumptions that physicians would be immune to financial instability, citing both the low salaries for those still in training and extensive student loan debt [49]. Environmental changes, reduced workload, uncertainty, and negative job expectations also constituted predictors for mental workload and the subsequent occurrence of poor mental health outcomes, like burnout, anxiety and depression symptoms, especially for some categories of workers, deeply damaged by the pandemic social and economic crisis $[39,67]$. Moreover, job insecurity, even at the beginning of the pandemic, was already being associated with higher levels of stress and lower wellbeing [29].

\section{Discussion}

This review tries to identify job dimensions that played a role in the psychological wellbeing of workers during the outgoing COVID pandemic. Despite the vaccination campaigns, the virus seems to remain endemic and long coexistence with the contagion is expected. Recognizing the main aspects to address in the management of the pandemic in the workplace, especially in this precise historic moment, is fundamental for the planning of interventions at various levels and for preparedness for possible future emergencies. The COVID-19 pandemic has shown us the importance of being deeply prepared for the unexpected events that can lead to change in people's daily life work habits. We identified five major topics in the work environment, which have affected the psychological wellbeing of workers during the pandemic, and which can be a target for specific interventions. First of all, in workplaces the need for support from peers and organizations seems to involve all work categories, from the HCW working in direct contact with the virus to remote workers. Low levels of support from peers and supervisors are associated with poor mental outcomes [68]. A supportive workplace environment, where workers can rely on their colleagues and supervisors is known to be one of the major issues when dealing with difficulties at work $[69,70]$. Peer support can be defined as "a system of giving and receiving help founded on key principles of respect, shared responsibility, and mutual agreement of what is helpful" [71]. The main support for workers within their organizations often comes from colleagues and managers [72]. Peer support at work strengthens psychological resilience by enhancing coping skills and the development of post-traumatic growth, factors which can protect workers involved in stressful situations [73,74]. In our review peer and organizational support during the COVID-19 pandemic was associated with post-traumatic disorder symptoms, anxiety and depression, occupational stress, job satisfaction, burnout, uncertainty at work, emotional exhaustion, moral injury, and sleep disturbances. We found that during the COVID pandemic, when occupational stress was at very high levels, peer support was a key factor for managing stress at work and it contributed to mitigating the job insecurity faced by several work categories $[30,75]$. It can be hypothesized that especially in the lockdown phases or in work overload periods, the support of colleagues could partially replace the support of families and friends, thus 
explaining the relevance of this issue in preventing and mitigating work stress. In this optic, investing in peer support programs may increase social support and develop resilience, which is a key factor in managing significant sources for stress or trauma [76]. Communication and team building training programs could help boost social support, especially in healthcare settings. Organizational support is another aspect linked to the maintenance of workers' mental wellbeing: the perception of organizational support refers to employees' global beliefs regarding the extent to which the organization values their contributions and cares about their wellbeing [77]. This organizational support not only motivates employees to work harder and fosters a bond to the company, but also protects workers from poor mental outcomes during this emergency phase [78]. Organizational changes can mitigate the impact of the emergency on workers, and clear and effective communication between colleagues and supervisors is a key factor that is needed to prevent poor mental outcomes. Organizational support can also be related to the provision of adequate training for workers. Training is defined as the process by which employees are provided with the knowledge and skills needed to function in their work environment [79]. Several studies highlighted the strain experienced by HCWs in their job as they did not feel prepared and did not have protocols to follow in order to treat COVID patients. Throughout our research, a lack of adequate training is associated to depression, anxiety, PTSD and burnout symptoms, as well as to general psychological distress, work-related stress and the loss of motivation. During the most acute phases of the pandemic in particular, HCWs have been deployed from one department to another, without receiving suitable training. These findings suggest the need for regular training programs, not only regarding professional topics, but also on emotional regulations and team-work training with a view to making employees feel supported and to decrease their feelings of perceived occupational stress and workload $[80,81]$. Healthcare organizations should provide adequate training programs; shared protocols and guidelines on managing the COVID-19 emergency are crucial to guiding HCWs in their job. Another occupational issue to have emerged during the pandemic is the change in workload. Workload is a traditional job demand item characterized by the need to work faster, to offer quicker responses, to reach several objectives at the same time and perform multiple tasks. According to the job-demand resource model [82], the work environment possesses job demands (e.g., workload, physical working conditions and physical demands) that exhaust employees' cognitive and physical resources, which result in health problems and a loss of energy. Occupational strain, which was even a worldwide problem among health professionals before the COVID-19 pandemic, became a major topic and an actual risk for healthcare personnel and we found that it was associated with emotional exhaustion, anxiety, depression, PTSD and burnout symptoms. This aspect is particularly relevant as it affects not only the single worker, but is known to have an impact on patients' safety, in particular in terms of medical errors reported [83]. Thus, it is essential that healthcare organizations provide enough time to recover from fatigue as rest is a priority for the wellbeing of both workers and patients. In this sense, the organization of work shifts can be a crucial factor for management to consider. Strictly connected to the increasing workload, we found that home-work imbalance was another relevant issue associated with mental health impairment during the pandemic. Work-life balance can be described as the balance that individuals need between the time allocated for work and other aspects of life, including family, social and leisure pursuits, and other domains of health and well-being [84]. The imbalance between home life and work life is associated in our review to perceived job productivity and satisfaction, occupational stress, and burnout symptoms. The connections between work and home life are crucial, especially in a society where double-paying couples are common. Even before the COVID19 pandemic, doctors experienced the stress derived from a poor balance between life at work and at home, often causing emotional exhaustion $[85,86]$. Childcare was one of the major concerns, for training doctors for example, as they were exposed to higher levels of workload. This specific psychosocial factor may affect female workers more than their male counterparts, configuring the need for an appropriate gender specific approach to 
the issue [87]. In this scenario, practical organizational support measures, such as flexible schedules, are relevant interventions that can address workers' issues and boost their mental wellbeing. Government and organizational measures in order to support family care can also support workers and protect their mental health. On the other hand, remote workers experienced a different kind of imbalance between work and home. If there was an overall appreciation of the possibility of working from home, remote working, which was widely adopted by companies since the very beginning of the pandemic, can often blur the line between work and free time, not allowing employees to take a substantial break from work [88]. Remote workers may experience the constant willingness to be connected to their work using information and communication technologies (ICT) and may tend to work longer than usual as ICTs create expectations for a faster response. In this sense, work-related technostress can emerge as a relevant risk factor. Technostress is "an IT user's experience of stress when using technologies" [89]. In workplaces, the ICT demands were associated with increased strain, stress, and burnout [90]: the massive adoption of remote working, which is probably set to last after the pandemic, needs further research involving the issue of technostress. Educating employees and supervisors to make a clear distinction between free time and work time can be a suitable intervention in mitigating the uneasiness derived from this issue. In our review we also found that the reduction in workload may cause poor mental outcomes, mainly linked to insecurity about the future and the loss of economic status. The mental outcomes associated with this dimension are anxiety, depression, PTSD and burnout symptoms, as well as work-related stress. Even the perception of job insecurity, which characterizes the job market during COVID-19, may have an impact on employees' financial anxiety. The job insecurity related to COVID was found to be associated with psychological wellbeing through financial stress [91] and is also linked to lower vitality. Interestingly, job insecurity also involved healthcare professionals, who found themselves in a sort of paradox, caught between high workload and financial instability. Government measures aimed at sustaining certain working categories can have an important impact on the mental status of workers and when possible, companies should provide job stabilization and economic support to workers.

A summary of main findings of the review and other implications are reported in Table 1.

\section{Strengths and Limitations}

This review has some strengths that need to be highlighted. First, it searched the literature after 18 months of COVID-19 pandemic, thus giving an updated overview of the mental outcomes in the workplace in the era of COVID-19. Moreover, the selection of articles focused on papers that gave insights into the working conditions during the pandemic and made some associations between mental outcomes and specific psychosocial factors in the workplace. Some specific interventional possibilities have been recognized that could protect and boost workers' mental health. Although this review adopted a qualitative approach, this is compliant with the PRISMA statement, which gives more strength to the evidence retrieved. Finally, unlike previous research, this review also focused on non HCWs workers, recognizing characteristics of work which had an impact on mental health during the pandemic and during emergencies in general. Nevertheless, some limitations should be addressed. Most of the studies selected have a cross-sectional design, thus limiting the strength of the conclusions and the possibility of making causal inferences. Moreover, data have been collected in different stages of the pandemic and in different countries, which may have affected the results, especially considering the heterogeneity in the management of pandemic in workplaces in the world. Another concern is related to the scales and tools used to test the participant and to adequacy in the selection of samples. 


\section{Conclusions}

Support from peers and organization, home-work balance, changes in workload, training and job insecurity are relevant topics for the mental wellbeing of workers during the pandemic. Recognizing these factors and projecting interventions in order to mitigate their effects, or to boost their efficacy, is a fundamental step in dealing with COVID-19 in the workplace and with future emergencies. The five dimensions retrieved play a fundamental role in the wellbeing of workers, HCWs and non HCWs, during the pandemic: they are associated to anxiety; depression; burnout; PTSD symptoms; and work-related stress. Intervening in these psychosocial risks, with specific programs from companies and policy makers, can prevent poor mental outcomes in workers during the ongoing COVID-19 pandemic.

Author Contributions: Conceptualization, L.G.L., G.G. and N.M.; methodology, L.G.L., G.G. and N.M.; software, L.G.L. and C.P.; validation, L.G.L., G.F. and G.L.F.; formal analysis, G.G., G.A. and N.M.; investigation, L.G.L., C.P. and G.F.; resources, L.G.L. and G.L.F.; data curation, G.G., N.M. and G.A.; writing —original draft preparation, L.G.L. and G.L.F.; writing—review and editing, G.G. and N.M.; visualization, L.G.L., G.G. and N.M.; supervision, G.A.; project administration, G.A.; funding acquisition, G.A. All authors have read and agreed to the published version of the manuscript.

Funding: This research received no external funding.

Conflicts of Interest: The authors declare no conflict of interest.

\section{Appendix A}

Table A1. Summary of the articles included in the review.

\begin{tabular}{|c|c|c|c|c|c|c|}
\hline Authors & $\begin{array}{c}\text { Sample/ } \\
\text { Country/ } \\
\text { Study Design }\end{array}$ & $\begin{array}{l}\text { Working } \\
\text { Population }\end{array}$ & Scale Used & $\begin{array}{c}\text { Intervention/ } \\
\text { Psychosocial } \\
\text { Risks Identified }\end{array}$ & $\begin{array}{l}\text { Mental } \\
\text { Outcomes }\end{array}$ & Main Results \\
\hline $\begin{array}{l}\text { Aguiar- } \\
\text { Quintana } \\
\text { et al. [67] }\end{array}$ & $\begin{array}{l}\text { 353/Spain/Cross- } \\
\text { sectional } \\
\text { study }\end{array}$ & $\begin{array}{l}\text { Hotel } \\
\text { employees }\end{array}$ & Ad hoc questionnaires & $\begin{array}{l}\text { Job insecurity and } \\
\text { financial stress }\end{array}$ & $\begin{array}{l}\text { Anxiety and } \\
\text { depression }\end{array}$ & $\begin{array}{c}\text { Job insecurity of } \\
\text { employees did not } \\
\text { significantly influence } \\
\text { Task Performance but was } \\
\text { positively and } \\
\text { significantly associated } \\
\text { with Anxiety and } \\
\text { Depression }\end{array}$ \\
\hline $\begin{array}{l}\text { Zhou et al. } \\
\text { [42] }\end{array}$ & $\begin{array}{l}\text { 107/China/Short- } \\
\text { term longitudinal } \\
\text { study }\end{array}$ & $\begin{array}{l}\text { Frontline } \\
\text { HCW }\end{array}$ & $\begin{array}{c}\text { The Chinese version of } \\
\text { Impact Event } \\
\text { Scale-Revised (CIES-R), } \\
\text { A perceived } \\
\text { organizational support } \\
\text { scale was developed, ad } \\
\text { hoc questionnaires for } \\
\text { coping strategies. }\end{array}$ & $\begin{array}{l}\text { Support from } \\
\text { peers and } \\
\text { organization }\end{array}$ & PTSD & $\begin{array}{l}\text { Perceived organizational } \\
\text { support had a significant } \\
\text { indirect effect on PTSD } \\
\text { symptoms. } \\
\text { Problem-focused coping } \\
\text { strategies and self-efficacy } \\
\text { mediate this effect. }\end{array}$ \\
\hline $\begin{array}{c}\text { Zhang J. et al., } \\
\text { [54] }\end{array}$ & $\begin{array}{l}\text { 4850/China/Cross- } \\
\text { sectional } \\
\text { study }\end{array}$ & $\begin{array}{l}\text { Frontline } \\
\text { HCW }\end{array}$ & $\begin{array}{c}\text { ERI questionnaire, the } \\
\text { 9-item Patient Health } \\
\text { Questionnaire (PHQ-9), } \\
\text { 7-item General } \\
\text { Anxiety Disorder Scale } \\
\text { (GAD-7). }\end{array}$ & $\begin{array}{l}\text { Changes in } \\
\text { workload and job } \\
\text { demand }\end{array}$ & $\begin{array}{l}\text { work stress, } \\
\text { depression, } \\
\text { anxiety }\end{array}$ & $\begin{array}{c}\text { Effort and } \\
\text { over-commitment were } \\
\text { positively associated with } \\
\text { depression and anxiety, } \\
\text { and negatively associated } \\
\text { with reward, through } \\
\text { development and job } \\
\text { acceptance. }\end{array}$ \\
\hline $\begin{array}{l}\text { Khajuria A. } \\
\text { et al. [17] }\end{array}$ & $\begin{array}{l}\text { 2527/Multiple } \\
\text { countries (China, } \\
\text { UK, USA)/Cross- } \\
\text { sectional } \\
\text { study }\end{array}$ & HCWs & $\begin{array}{c}\text { Patient Health } \\
\text { Questionnaire-2 } \\
\text { (PHQ-2); questionnaires } \\
\text { ad hoc for workplace } \\
\text { factors }\end{array}$ & $\begin{array}{l}\text { Work competence } \\
\text { and adequate } \\
\text { training/Support } \\
\text { from peers and } \\
\text { organizations }\end{array}$ & $\begin{array}{l}\text { Depressive } \\
\text { symptoms }\end{array}$ & $\begin{array}{l}\text { Poor training and poor } \\
\text { support in the workplace, } \\
\text { including being } \\
\text { redeployed without } \\
\text { adequate training, were } \\
\text { all highly significant } \\
\text { correlated to more } \\
\text { depressive symptoms., }\end{array}$ \\
\hline
\end{tabular}


Table A1. Cont.

\begin{tabular}{|c|c|c|c|c|c|c|}
\hline Authors & $\begin{array}{c}\text { Sample/ } \\
\text { Country/ } \\
\text { Study Design }\end{array}$ & $\begin{array}{l}\text { Working } \\
\text { Population }\end{array}$ & Scale Used & $\begin{array}{c}\text { Intervention/ } \\
\text { Psychosocial } \\
\text { Risks Identified }\end{array}$ & $\begin{array}{c}\text { Mental } \\
\text { Outcomes }\end{array}$ & Main Results \\
\hline $\begin{array}{l}\text { Gilleen J. et al. } \\
\text { [55] }\end{array}$ & $\begin{array}{c}\text { 2773/UK/Cross- } \\
\text { sectional } \\
\text { study }\end{array}$ & $\mathrm{HCW}$ & $\begin{array}{c}\text { Patient Health } \\
\text { Questionnaire (PHQ-9), } \\
\text { General Anxiety } \\
\text { Disorder-7 (GAD-7), } \\
\text { 22-item Impact of Event } \\
\text { Scale-Revised (IES-R)1; } \\
\text { ad hoc questionnaires } \\
\text { on work conditions and } \\
\text { possible factors of } \\
\text { anxiety and depression }\end{array}$ & $\begin{array}{l}\text { Support from } \\
\text { peers and organi- } \\
\text { zation/Changes } \\
\text { in workload and } \\
\text { job demand }\end{array}$ & $\begin{array}{l}\text { Anxiety and } \\
\text { depression } \\
\text { symptoms }\end{array}$ & $\begin{array}{l}\text { Insufficient personal } \\
\text { protective equipment } \\
\text { availability, workplace } \\
\text { preparation, training and } \\
\text { communication, and } \\
\text { higher workload were } \\
\text { associated with anxiety } \\
\text { and depression symptoms. } \\
\text { Sharing stress, resilience } \\
\text { and ethical support were } \\
\text { associated with better } \\
\text { psychological outcomes. }\end{array}$ \\
\hline $\begin{array}{l}\text { Escudero- } \\
\text { Castillo I. } \\
\text { et al. [43] }\end{array}$ & $\begin{array}{c}\text { 1050/Spain/Cross- } \\
\text { sectional } \\
\text { study }\end{array}$ & $\begin{array}{l}\text { Workers } \\
\text { not further } \\
\text { specified }\end{array}$ & Ad hoc questionnaires & $\begin{array}{l}\text { Home-work } \\
\text { interface and } \\
\text { balance }\end{array}$ & $\begin{array}{c}\text { Personal } \\
\text { wellbeing }\end{array}$ & $\begin{array}{l}\text { The lockdown exerted a } \\
\text { greater negative effect on } \\
\text { the self-perceived } \\
\text { wellbeing of unemployed } \\
\text { and furloughed persons } \\
\text { than on those in } \\
\text { employment. Teleworkers } \\
\text { experienced a lesser } \\
\text { degree of self-perceived } \\
\text { wellbeing post lockdown } \\
\text { as compared to those } \\
\text { people remaining in the } \\
\text { same work location. }\end{array}$ \\
\hline $\begin{array}{l}\text { Babore A. } \\
\text { et al. [30] }\end{array}$ & $\begin{array}{l}\text { 595/Italy/Cross- } \\
\text { sectional } \\
\text { study }\end{array}$ & HCWs & $\begin{array}{l}\text { Perceived Stress Scale } \\
\text { (PSS-10); } \\
\text { The COPE-New Italian } \\
\text { Version (COPE-NVI-25 }\end{array}$ & $\begin{array}{l}\text { Support from } \\
\text { peers and } \\
\text { organization }\end{array}$ & $\begin{array}{l}\text { Occupational } \\
\text { stress }\end{array}$ & $\begin{array}{l}\text { Lower positive attitude, } \\
\text { higher social support, } \\
\text { working with COVID-19 } \\
\text { patients and higher } \\
\text { avoidance strategies } \\
\text { predicted higher levels of } \\
\text { distress. The higher the } \\
\text { positive attitude, the } \\
\text { lower distress, while } \\
\text { social support and } \\
\text { avoidance constituted risk } \\
\text { factors for work-related } \\
\text { stress. }\end{array}$ \\
\hline $\begin{array}{l}\text { Bulinska- } \\
\text { Stangrecka H. } \\
\text { et al. [24] }\end{array}$ & $\begin{array}{l}\text { 220/Poland/Cross- } \\
\text { sectional } \\
\text { study }\end{array}$ & $\begin{array}{c}\text { IT } \\
\text { employees }\end{array}$ & Ad hoc questionnaires & $\begin{array}{l}\text { Support from } \\
\text { peers and } \\
\text { organization }\end{array}$ & $\begin{array}{c}\text { Job } \\
\text { satisfaction }\end{array}$ & $\begin{array}{c}\text { Employee relations } \\
\text { including interpersonal } \\
\text { trust support, help } \\
\text { building job satisfaction, } \\
\text { even in a virtual space } \\
\text { and remotely. }\end{array}$ \\
\hline $\begin{array}{l}\text { Afulani P.A. } \\
\text { et al. [35] }\end{array}$ & $\begin{array}{l}\text { 414/Ghana/Cross- } \\
\text { sectional }\end{array}$ & $\mathrm{HCW}$ & $\begin{array}{c}\text { 10-item Cohen } \\
\text { perceived stress scale. } \\
\text { Burnout was assessed } \\
\text { using the 14-item } \\
\text { Shirom-Melamed } \\
\text { Burnout measure } \\
\text { (SMBM), ad hoc } \\
\text { questionnaires }\end{array}$ & $\begin{array}{l}\text { Support from } \\
\text { peers and } \\
\text { organization }\end{array}$ & $\begin{array}{l}\text { Job stress, } \\
\text { burnout }\end{array}$ & $\begin{array}{l}\text { Healthcare workers who } \\
\text { felt somewhat prepared } \\
\text { and } \\
\text { appreciated/experienced } \\
\text { support from } \\
\text { management and support } \\
\text { by family had lower stress } \\
\text { and burnout scores than } \\
\text { those who did not feel } \\
\text { prepared. Fear of infection } \\
\text { was associated with } \\
\text { higher stress and burnout. }\end{array}$ \\
\hline
\end{tabular}


Table A1. Cont.

\begin{tabular}{|c|c|c|c|c|c|c|}
\hline Authors & $\begin{array}{c}\text { Sample/ } \\
\text { Country/ } \\
\text { Study Design }\end{array}$ & $\begin{array}{l}\text { Working } \\
\text { Population }\end{array}$ & Scale Used & $\begin{array}{c}\text { Intervention/ } \\
\text { Psychosocial } \\
\text { Risks Identified }\end{array}$ & $\begin{array}{c}\text { Mental } \\
\text { Outcomes }\end{array}$ & Main Results \\
\hline $\begin{array}{l}\text { Charoensuk- } \\
\text { mongkol P. } \\
\text { et al. [31] }\end{array}$ & $\begin{array}{l}\text { 300/Thailand/ } \\
\text { cross-sectional }\end{array}$ & $\begin{array}{l}\text { University } \\
\text { employees }\end{array}$ & $\begin{array}{l}\text { Adapted scale for } \\
\text { Uncertainty at work, } \\
\text { supervisor support was } \\
\text { measured using the } \\
\text { scale of Cole et al. } \\
\text { (2006); Emotional } \\
\text { Exhaustion was } \\
\text { measured using the } \\
\text { scale of Maslach and } \\
\text { Jackson; Organizational } \\
\text { Intransigence was } \\
\text { measured using the } \\
\text { scale of Patterson et al. } \\
\text { (2005). }\end{array}$ & $\begin{array}{l}\text { Support from } \\
\text { peers and } \\
\text { organization }\end{array}$ & $\begin{array}{l}\text { Uncertainty } \\
\text { at work, } \\
\text { emotional } \\
\text { exhaustion }\end{array}$ & $\begin{array}{l}\text { Perceived uncertainties } \\
\text { were associated with } \\
\text { emotional exhaustion. } \\
\text { Supervisor support has a } \\
\text { negative effect on the } \\
\text { perceived uncertainties of } \\
\text { employees, however this } \\
\text { support can be } \\
\text { suppressed by } \\
\text { organizational } \\
\text { intransigence. }\end{array}$ \\
\hline $\begin{array}{l}\text { Cipolotti L. } \\
\text { et al. [25] }\end{array}$ & $\begin{array}{c}\text { 158/UK/cross } \\
\text { sectional }\end{array}$ & $\begin{array}{l}\text { Hospital } \\
\text { employees } \\
\text { (HCW and } \\
\text { non HCW) }\end{array}$ & $\begin{array}{l}\text { Ad hoc questionnaire } \\
\text { assessing psychological } \\
\text { impact of COVID }\end{array}$ & $\begin{array}{l}\text { Changes in } \\
\text { workload and job } \\
\text { demand/Work } \\
\text { competence and } \\
\text { adequate training }\end{array}$ & $\begin{array}{l}\text { Psychological } \\
\text { distress }\end{array}$ & $\begin{array}{l}\text { Work challenges } \\
\text { (performance at } \\
\text { work/making mistakes, } \\
\text { changes to role/hours } \\
\text { worked/shift patterns, } \\
\text { discussions with dying } \\
\text { patients families, dealing } \\
\text { with families), and social } \\
\text { change (distancing from } \\
\text { family, not doing regular } \\
\text { activities) predicted } \\
\text { psychological distress }\end{array}$ \\
\hline $\begin{array}{l}\text { Elbay R.Y. } \\
\text { et al. [18] }\end{array}$ & $\begin{array}{c}\text { 442/Turkey/cross } \\
\text { sectional }\end{array}$ & $\begin{array}{l}\mathrm{HCW} \text { on } \\
\text { frontline } \\
\text { and not }\end{array}$ & $\begin{array}{l}\text { DAS-21; specific } \\
\text { questionnaires on } \\
\text { working conditions }\end{array}$ & $\begin{array}{c}\text { Support from } \\
\text { peers and organi- } \\
\text { zation/Changes } \\
\text { in workload and } \\
\text { job } \\
\text { demand/Work } \\
\text { competence and } \\
\text { adequate training }\end{array}$ & $\begin{array}{l}\text { Depression } \\
\text { and anxiety } \\
\text { symptoms }\end{array}$ & $\begin{array}{l}\text { Increased weekly working } \\
\text { hours, increased number } \\
\text { of COVID-19 patients } \\
\text { cared for, lower level of } \\
\text { support from peers and } \\
\text { supervisors, lower logistic } \\
\text { support and lower } \\
\text { feelings of competence } \\
\text { during COVID-19 related } \\
\text { tasks were associated with } \\
\text { higher DAS-21 total } \\
\text { scores. }\end{array}$ \\
\hline $\begin{array}{l}\text { Gómez- } \\
\text { Galán J. Et al. } \\
\text { [32] }\end{array}$ & $\begin{array}{l}\text { 2182/Spain/cross- } \\
\text { sectional }\end{array}$ & $\begin{array}{c}\text { Security } \\
\text { workforce }\end{array}$ & $\begin{array}{l}\text { Maslach Burnout } \\
\text { Inventory (MBI) scale; } \\
\text { ad hoc questionnaire for } \\
\text { subjective perceptions } \\
\text { about their working } \\
\text { conditions } \\
\text { and the need for } \\
\text { psychological and } \\
\text { psychiatric treatment; } \\
\text { the Death Anxiety Scale. }\end{array}$ & $\begin{array}{l}\text { Support from } \\
\text { peers and } \\
\text { organization }\end{array}$ & Burnout & $\begin{array}{l}\text { Stress and anxiety levels } \\
\text { increased in work as a } \\
\text { result of not having the } \\
\text { basic supplies for their } \\
\text { personal protection. Most } \\
\text { workers reported that } \\
\text { they have not felt } \\
\text { recognized in their } \\
\text { professional activity by } \\
\text { their institution. }\end{array}$ \\
\hline $\begin{array}{l}\text { Hines S.E. } \\
\text { et al. [41] }\end{array}$ & $\begin{array}{l}\text { 96/USA/ } \\
\text { longitudinal } \\
\text { study }\end{array}$ & $\mathrm{HCW}$ & $\begin{array}{l}\text { Impact of Events } \\
\text { Scale-Revised (IES-R) } \\
\text { Moral Injury Events } \\
\text { Scale (MIES); specific } \\
\text { questionnaires on } \\
\text { occupational factors }\end{array}$ & $\begin{array}{l}\text { Support from } \\
\text { peers and } \\
\text { organization }\end{array}$ & Moral injury & $\begin{array}{l}\text { A supportive workplace } \\
\text { environment was related } \\
\text { to lower moral injury, } \\
\text { whereas a stressful, less } \\
\text { supportive environment } \\
\text { was associated with } \\
\text { increased moral injury. }\end{array}$ \\
\hline
\end{tabular}


Table A1. Cont.

\begin{tabular}{|c|c|c|c|c|c|c|}
\hline Authors & $\begin{array}{c}\text { Sample/ } \\
\text { Country/ } \\
\text { Study Design }\end{array}$ & $\begin{array}{l}\text { Working } \\
\text { Population }\end{array}$ & Scale Used & $\begin{array}{c}\text { Intervention/ } \\
\text { Psychosocial } \\
\text { Risks Identified }\end{array}$ & $\begin{array}{c}\text { Mental } \\
\text { Outcomes }\end{array}$ & Main Results \\
\hline $\begin{array}{l}\text { Kannampalli } \\
\text { T. et al. [46] }\end{array}$ & $\begin{array}{c}\text { 393/USA/cross } \\
\text { sectional }\end{array}$ & $\begin{array}{l}\text { Physician } \\
\text { trainees }\end{array}$ & $\begin{array}{l}\text { DASS-21; Stanford } \\
\text { Professional Fulfillment } \\
\text { Index (PFI). Specific } \\
\text { questionnaires on } \\
\text { work-family balance } \\
\text { and perceived life } \\
\text { stressors }\end{array}$ & $\begin{array}{l}\text { Home-work } \\
\text { interface and } \\
\text { balance }\end{array}$ & $\begin{array}{l}\text { Burnout, } \\
\text { stress }\end{array}$ & $\begin{array}{l}\text { The group exposed to } \\
\text { COVID-19 patients } \\
\text { experienced moderate to } \\
\text { extremely high perceived } \\
\text { stress regarding childcare } \\
\text { and considerably lower } \\
\text { work-family balance. Their } \\
\text { job duties interfered with } \\
\text { their family life, and they } \\
\text { experienced more difficulty } \\
\text { in taking time off for } \\
\text { attending to personal or } \\
\text { family matters. }\end{array}$ \\
\hline $\begin{array}{l}\text { Labrague L. } \\
\text { et al. [19] }\end{array}$ & $\begin{array}{l}\text { 325/Philippines/ } \\
\text { cross-sectional }\end{array}$ & Nurses & $\begin{array}{l}\text { COVID-19 Anxiety } \\
\text { Scale, the Brief Resilient } \\
\text { Coping Scale (BRCS), } \\
\text { the Perceived Social } \\
\text { Support Questionnaire } \\
\text { (PSSQ) and the } \\
\text { Perceived } \\
\text { Organizational Support } \\
\text { (POS) questionnaire }\end{array}$ & $\begin{array}{l}\text { Support from } \\
\text { peers and } \\
\text { organization }\end{array}$ & $\begin{array}{c}\text { Anxiety } \\
\text { symptoms }\end{array}$ & $\begin{array}{l}\text { Social support, personal } \\
\text { resilience and } \\
\text { organizational support } \\
\text { predicted COVID-19 } \\
\text { anxiety. Increased scores } \\
\text { in the social support, } \\
\text { organizational support } \\
\text { and personal resilience } \\
\text { measures were associated } \\
\text { with lower COVID-19 } \\
\text { related anxiety. }\end{array}$ \\
\hline $\begin{array}{l}\text { Magnavita N. } \\
\text { et al. [64] }\end{array}$ & $\begin{array}{c}\text { 155/Italy/cross- } \\
\text { sectional }\end{array}$ & Anesthetists & $\begin{array}{l}\text { Specific questionnaires } \\
\text { on changes in } \\
\text { occupation and } \\
\text { lifestyles; Effort-Reward } \\
\text { Imbalance } \\
\text { questionnaire, Colquitt } \\
\text { Scale (organizational } \\
\text { justice), Goldberg } \\
\text { Anxiety and Depression } \\
\text { Scale (GADS). }\end{array}$ & $\begin{array}{c}\text { Changes in } \\
\text { workload and job } \\
\text { demand/Work } \\
\text { competence and } \\
\text { adequate training }\end{array}$ & $\begin{array}{l}\text { Occupational } \\
\text { stress, anxiety } \\
\text { symptoms }\end{array}$ & $\begin{array}{l}\text { A significant increase in } \\
\text { workload was associated } \\
\text { with work-related stress } \\
\text { and low perceived levels of } \\
\text { organizational justice. } \\
\text { Workers experienced little } \\
\text { ability to influence and } \\
\text { change the outcome of } \\
\text { procedures. Levels of } \\
\text { anxiety and depression } \\
\text { were significantly } \\
\text { correlated with work effort. }\end{array}$ \\
\hline $\begin{array}{l}\text { Manzano- } \\
\text { Garcia G. } \\
\text { et al. [36]. }\end{array}$ & $\begin{array}{l}771 / \text { Spain/cross } \\
\text { sectional }\end{array}$ & Nurses & $\begin{array}{l}\text { Questionnaire on } \\
\text { socio-demographic data; } \\
\text { Spanish Burnout } \\
\text { Inventory (CESQT) for } \\
\text { burnout, the UNIPSICO } \\
\text { Battery for the } \\
\text { evaluation of certain } \\
\text { psychosocial factors of } \\
\text { demand and resources in } \\
\text { the context of work; ad } \\
\text { hoc scale for perceived } \\
\text { threat of COVID-19 }\end{array}$ & $\begin{array}{l}\text { Changes in } \\
\text { workload and job } \\
\text { demand/Support } \\
\text { from peers and } \\
\text { organization }\end{array}$ & Burnout & $\begin{array}{l}\text { Work overload, material } \\
\text { and human resources and } \\
\text { social support at work } \\
\text { were significant in } \\
\text { explaining burnout. } \\
\text { The perceived threat of } \\
\text { COVID-19 moderated the } \\
\text { relationship between } \\
\text { social support at work } \\
\text { and burnout. }\end{array}$ \\
\hline $\begin{array}{l}\text { Marco C.A.et } \\
\text { al. [48] }\end{array}$ & $\begin{array}{c}\text { 1300/USA/cross- } \\
\text { sectional }\end{array}$ & $\begin{array}{l}\text { Emergency } \\
\text { Physicians }\end{array}$ & $\begin{array}{c}\text { Life Events Checklist for } \\
\text { DSM-5, the PTSD } \\
\text { Checklist for DSM-5 }\end{array}$ & $\begin{array}{l}\text { Changes in } \\
\text { workload and job } \\
\text { demand/Work } \\
\text { competence and } \\
\text { adequate } \\
\text { training/Job } \\
\text { insecurity and } \\
\text { financial stress }\end{array}$ & $\begin{array}{l}\text { PTSD/work } \\
\text { related stress }\end{array}$ & $\begin{array}{c}\text { The major sources of stress } \\
\text { identified by participants } \\
\text { included disinformation } \\
\text { about COVID-19, } \\
\text { computer work/electronic } \\
\text { medical record, PPE } \\
\text { concerns, and workload. } \\
\text { Financial stress related to } \\
\text { reduced patient volume } \\
\text { and concerns about } \\
\text { work-home imbalance } \\
\text { were present, especially in } \\
\text { those caring for } \\
\text { homeschooling children. } \\
\text { This played a role in the } \\
\text { stress perceived. }\end{array}$ \\
\hline
\end{tabular}


Table A1. Cont.

\begin{tabular}{|c|c|c|c|c|c|c|}
\hline Authors & $\begin{array}{c}\text { Sample/ } \\
\text { Country/ } \\
\text { Study Design }\end{array}$ & $\begin{array}{l}\text { Working } \\
\text { Population }\end{array}$ & Scale Used & $\begin{array}{c}\text { Intervention/ } \\
\text { Psychosocial } \\
\text { Risks Identified }\end{array}$ & $\begin{array}{c}\text { Mental } \\
\text { Outcomes }\end{array}$ & Main Results \\
\hline $\begin{array}{l}\text { Mattila E.et } \\
\text { al. [20] }\end{array}$ & $\begin{array}{l}\text { 1079/Finland/ } \\
\text { cross-sectional }\end{array}$ & $\begin{array}{l}\text { Hospital } \\
\text { staff }\end{array}$ & $\begin{array}{c}\text { Generalized Anxiety } \\
\text { Disorder 7-item scale } \\
\text { (GAD-7), specific } \\
\text { questionnaires on } \\
\text { demographic data, } \\
\text { changes in work, } \\
\text { interaction between } \\
\text { co-workers, } \\
\text { psychological distress } \\
\text { linked to work, fear of } \\
\text { contagion. }\end{array}$ & $\begin{array}{l}\text { Support from } \\
\text { peers and organi- } \\
\text { zation/Changes } \\
\text { in workload and } \\
\text { job demand }\end{array}$ & $\begin{array}{c}\text { Anxiety } \\
\text { symptoms }\end{array}$ & $\begin{array}{l}\text { Anxiety symptoms were } \\
\text { associated with: young } \\
\text { age, working in a } \\
\text { university hospital, } \\
\text { problems in cooperation } \\
\text { between co-workers, } \\
\text { difficulty concentrating at } \\
\text { work, a health-threatening } \\
\text { physical and } \\
\text { psychological workload, } \\
\text { and a fear of being } \\
\text { infected at work. }\end{array}$ \\
\hline $\begin{array}{l}\text { Moretti A. } \\
\text { et al. [44] }\end{array}$ & $\begin{array}{c}51 / \text { Italy/cross- } \\
\text { sectional }\end{array}$ & $\begin{array}{l}\text { Home } \\
\text { working } \\
\text { population } \\
\text { (put in } \\
\text { remote } \\
\text { worker } \\
\text { since the } \\
\text { beginning } \\
\text { of } \\
\text { pandemic) }\end{array}$ & $\begin{array}{c}\text { Utrecht Work } \\
\text { Engagement Scale } \\
\text { (UWES) for job } \\
\text { satisfaction, Brief Pain } \\
\text { Inventory (BPI) and } \\
\text { Fear Avoidance Beliefs } \\
\text { Questionnaire (FABQ) } \\
\text { for MSK issues; ad hoc } \\
\text { questionnaire for } \\
\text { structural aspects of the } \\
\text { workplace at home }\end{array}$ & $\begin{array}{l}\text { Home-work } \\
\text { interface and } \\
\text { balance }\end{array}$ & $\begin{array}{l}\text { Perceived job } \\
\text { productivity } \\
\text { and } \\
\text { satisfaction, } \\
\text { work-related } \\
\text { stress, and } \\
\text { muscu- } \\
\text { loskeletal } \\
\text { (MSK) issues. }\end{array}$ & $\begin{array}{l}\text { Thirty-nine percent of the } \\
\text { subjects working from } \\
\text { home self-perceived to be } \\
\text { less productive but less } \\
\text { stressed, while } 51 \% \text { were } \\
\text { equally satisfied. Among } \\
\text { mobile working } \\
\text { advantages, the most } \\
\text { appreciated was saved } \\
\text { travel time and the least } \\
\text { appreciated was greater } \\
\text { autonomy. Impaired } \\
\text { interaction with } \\
\text { colleagues and } \\
\text { distractions in the } \\
\text { domestic environment } \\
\text { were the worst } \\
\text { disadvantages }\end{array}$ \\
\hline $\begin{array}{l}\text { Morgantini } \\
\text { L.A.et al. [47] }\end{array}$ & $\begin{array}{l}2707 / \text { Various } \\
\text { countries (USA, } \\
\text { Italy, Brazil, } \\
\text { Sweden, } \\
\text { others)/cross } \\
\text { sectional }\end{array}$ & $\begin{array}{l}\text { Healthcare } \\
\text { workers }\end{array}$ & $\begin{array}{l}\text { Ad hoc questionnaire } \\
\text { containing questions } \\
\text { covering three major } \\
\text { domains of HCPs } \\
\text { experience (exposure, } \\
\text { perception, and } \\
\text { workload) }\end{array}$ & $\begin{array}{c}\text { Home-work } \\
\text { interface and } \\
\text { balance/Work } \\
\text { competence and } \\
\text { adequate training }\end{array}$ & Burnout & $\begin{array}{l}\text { Burnout was associated } \\
\text { with work impacting } \\
\text { household activities, } \\
\text { feeling pushed beyond } \\
\text { training, exposure to } \\
\text { COVID-19 patients and } \\
\text { making life prioritizing } \\
\text { decisions. Burnout was } \\
\text { higher in high-income } \\
\text { countries compared to } \\
\text { low- and middle-income } \\
\text { countries. }\end{array}$ \\
\hline $\begin{array}{l}\text { Portoghese I. } \\
\text { et al. [50] }\end{array}$ & $\begin{array}{l}521 / \text { Italy/cross- } \\
\text { sectional }\end{array}$ & Physicians & $\begin{array}{l}\text { Ad hoc questionnaire } \\
\text { on organizational } \\
\text { preparedness, personal } \\
\text { preparedness concerns } \\
\text { about catching } \\
\text { COVID-19; perceived } \\
\text { impact on personal job } \\
\text { (role and demand) and } \\
\text { on personal life, } \\
\text { perceived job stress, } \\
\text { rumination about the } \\
\text { pandemic, crying at } \\
\text { work. }\end{array}$ & $\begin{array}{l}\text { Changes in } \\
\text { workload and job } \\
\text { demand/Home- } \\
\text { work interface } \\
\text { and balance }\end{array}$ & Job stress & $\begin{array}{l}\text { The risk factors for } \\
\text { perceived job stress were } \\
\text { concerns about catching } \\
\text { COVID-19, perceived } \\
\text { impact on job demands, } \\
\text { perceived impact on job } \\
\text { role and non-working } \\
\text { concerns (fear of infecting } \\
\text { relatives and friends). }\end{array}$ \\
\hline
\end{tabular}


Table A1. Cont.

\begin{tabular}{|c|c|c|c|c|c|c|}
\hline Authors & $\begin{array}{c}\text { Sample/ } \\
\text { Country/ } \\
\text { Study Design }\end{array}$ & $\begin{array}{l}\text { Working } \\
\text { Population }\end{array}$ & Scale Used & $\begin{array}{c}\text { Intervention/ } \\
\text { Psychosocial } \\
\text { Risks Identified }\end{array}$ & $\begin{array}{c}\text { Mental } \\
\text { Outcomes }\end{array}$ & Main Results \\
\hline $\begin{array}{l}\text { Soto-Rubio A. } \\
\text { et al. [37] }\end{array}$ & $\begin{array}{c}125 / \text { Spain/cross- } \\
\text { sectional }\end{array}$ & Nurses & $\begin{array}{c}\text { Trait Meta-Mood Scale } \\
\text { (TMMS-24) for } \\
\text { emotional intelligence, } \\
\text { UNIPSICO Battery for } \\
\text { psychosocial risks, } \\
\text { Interpersonal conflicts } \\
\text { scale, Lack of } \\
\text { organizational justice } \\
\text { scale, Role conflict scale, } \\
\text { Workload scale Social } \\
\text { support scale, Job } \\
\text { satisfaction scale, } \\
\text { Frankfurt Emotional } \\
\text { Work Scale (FEWS), } \\
\text { Questionnaire for the } \\
\text { Assessment of } \\
\text { Workplace Burnout } \\
\text { Syndrome (CESQT) }\end{array}$ & $\begin{array}{l}\text { Support from } \\
\text { peers and } \\
\text { organization }\end{array}$ & $\begin{array}{l}\text { Job stress, } \\
\text { burnout }\end{array}$ & $\begin{array}{l}\text { The emotional intelligence } \\
\text { of nurses can influence } \\
\text { interpersonal conflicts or } \\
\text { lack of organizational } \\
\text { justice at work. Emotional } \\
\text { repair component can be a } \\
\text { factor that when } \\
\text { enhanced can prevent the } \\
\text { possible adverse effects } \\
\text { related to burnout and job } \\
\text { satisfaction. }\end{array}$ \\
\hline $\begin{array}{l}\text { Tušl M. et al. } \\
{[45]}\end{array}$ & $\begin{array}{c}\text { 2118/Switzerland, } \\
\text { Germany/cross } \\
\text { sectional }\end{array}$ & Employees & $\begin{array}{l}\text { Warwick-Edinburgh } \\
\text { Mental Well-Being Scale } \\
\text { (WEMWBS), ad hoc } \\
\text { questionnaires for } \\
\text { impact of COVID in life } \\
\text { and change in work }\end{array}$ & $\begin{array}{l}\text { Home-work } \\
\text { interface and } \\
\text { balance/Changes } \\
\text { in workload and } \\
\text { job demand }\end{array}$ & $\begin{array}{l}\text { Mental } \\
\text { wellbeing } \\
\text { and } \\
\text { self-reported } \\
\text { health }\end{array}$ & $\begin{array}{l}\text { Mandatory short-time } \\
\text { work was strongly } \\
\text { associated with perceived } \\
\text { negative impact on work } \\
\text { life, while work from } \\
\text { home, particularly if } \\
\text { experienced for the first } \\
\text { time, was strongly } \\
\text { associated with a } \\
\text { perceived positive impact } \\
\text { on work life. Perceived } \\
\text { negative impact of the } \\
\text { crisis on work and private } \\
\text { life and mandatory } \\
\text { short-time work were } \\
\text { associated with lower } \\
\text { mental wellbeing and } \\
\text { self-reported health. }\end{array}$ \\
\hline $\begin{array}{l}\text { Yang Y. et al. } \\
{[21]}\end{array}$ & $\begin{array}{c}\text { 2878/China/cross } \\
\text { sectional }\end{array}$ & HCWs & $\begin{array}{l}\text { Chinese version of the } \\
\text { Workplace Violence } \\
\text { Scale, 9-item Patient } \\
\text { Health Questionnaire } \\
\text { (PHQ-9). The 7-item } \\
\text { General Anxiety } \\
\text { Disorder Questionnaire } \\
\text { (GAD),The 26- } \\
\text { itemWorld Health } \\
\text { Organization Quality of } \\
\text { Life Questionnaire } \\
\text { (WHOQOL-BREF) }\end{array}$ & $\begin{array}{l}\text { Support from } \\
\text { peers and } \\
\text { organization }\end{array}$ & $\begin{array}{l}\text { Depression, } \\
\text { anxiety }\end{array}$ & $\begin{array}{c}\text { Frontline clinicians' } \\
\text { experience of workplace } \\
\text { violence directly affected } \\
\text { quality of life and } \\
\text { emotional disturbances } \\
\text { partly mediated the } \\
\text { association between } \\
\text { workplace violence and } \\
\text { the quality of life }\end{array}$ \\
\hline Zandi G. [38] & $\begin{array}{l}\text { 129/Pakistan/ } \\
\text { cross-sectional }\end{array}$ & Physicians & $\begin{array}{l}\text { Perceived stress scale } \\
\text { for job stress, scale for } \\
\text { extent of exposure to } \\
\text { COVID, scale adapted } \\
\text { from Survey of } \\
\text { Perceived } \\
\text { Organizational Support } \\
\text { (SPOS) for } \\
\text { organizational support }\end{array}$ & $\begin{array}{l}\text { Support from } \\
\text { peers and } \\
\text { organization }\end{array}$ & Job stress & $\begin{array}{l}\text { Perceived organizational } \\
\text { support moderated the } \\
\text { relationship between the } \\
\text { extent of exposure and } \\
\text { stress. The relationship } \\
\text { appeared weaker when } \\
\text { organizational support } \\
\text { was perceived high; the } \\
\text { relationship was stronger } \\
\text { with a low level of } \\
\text { perceived organizational } \\
\text { support. }\end{array}$ \\
\hline
\end{tabular}


Table A1. Cont.

\begin{tabular}{|c|c|c|c|c|c|c|}
\hline Authors & $\begin{array}{c}\text { Sample/ } \\
\text { Country/ } \\
\text { Study Design }\end{array}$ & $\begin{array}{l}\text { Working } \\
\text { Population }\end{array}$ & Scale Used & $\begin{array}{c}\text { Intervention/ } \\
\text { Psychosocial } \\
\text { Risks Identified }\end{array}$ & $\begin{array}{c}\text { Mental } \\
\text { Outcomes }\end{array}$ & Main Results \\
\hline $\begin{array}{l}\text { Zerbini G. } \\
\text { et al. [65] }\end{array}$ & $\begin{array}{l}\text { 110/Germany/ } \\
\text { cross sectional }\end{array}$ & $\begin{array}{l}\text { Nurses and } \\
\text { physicians }\end{array}$ & $\begin{array}{c}\text { Patient Health } \\
\text { Questionnaire(PHQ) the } \\
\text { Maslach Burnout } \\
\text { INventory (MBI), } \\
\text { specific scale for fear of } \\
\text { COVID infection and } \\
\text { stress at work, open } \\
\text { questions. }\end{array}$ & $\begin{array}{l}\text { Changes in } \\
\text { workload and job } \\
\text { demand/Job } \\
\text { insecurity and } \\
\text { financial stress }\end{array}$ & $\begin{array}{l}\text { Depression } \\
\text { symptoms, } \\
\text { burnout }\end{array}$ & $\begin{array}{l}\text { The most common causes } \\
\text { for burden were job strain } \\
\text { and uncertainty about the } \\
\text { future. Psychosocial } \\
\text { support as well as leisure } \\
\text { time were listed important } \\
\text { resources, and a better } \\
\text { infrastructure adjustment } \\
\text { to COVID-19 at the } \\
\text { hospital (e.g., sufficient } \\
\text { staff, keeping teams and } \\
\text { working schedules } \\
\text { stable)as suggestion for } \\
\text { improvement. }\end{array}$ \\
\hline $\begin{array}{l}\text { Zhang X. } \\
\text { et al. [54] }\end{array}$ & $\begin{array}{l}\text { 524/China/cross } \\
\text { sectional }\end{array}$ & $\begin{array}{l}\text { Medical } \\
\text { Staff }\end{array}$ & $\begin{array}{c}\text { Generalized Anxiety } \\
\text { Disorder Scale, the } \\
\text { Patient Health } \\
\text { Questionnaire, the } \\
\text { Insomnia Severity } \\
\text { Index, the Occupational } \\
\text { stress Questionnaire. }\end{array}$ & $\begin{array}{l}\text { Changes in } \\
\text { workload and job } \\
\text { demand }\end{array}$ & $\begin{array}{l}\text { anxiety and } \\
\text { depression } \\
\text { symptoms, } \\
\text { job stress }\end{array}$ & $\begin{array}{l}\text { Working intensity, } \\
\text { working time, working } \\
\text { difficulty and working } \\
\text { risk were correlated } \\
\text { positively with mental } \\
\text { health symptoms. A } \\
\text { significant association was } \\
\text { found between } \\
\text { occupational stress and } \\
\text { mental health symptoms } \\
\text { in both frontline and } \\
\text { non-frontline medical } \\
\text { staff during COVID-19 } \\
\text { outbreak. }\end{array}$ \\
\hline $\begin{array}{l}\text { Lee H. et al. } \\
\text { [40] }\end{array}$ & $\begin{array}{l}\text { 131/Singapore/ } \\
\text { cross sectional }\end{array}$ & $\begin{array}{l}\text { Remote } \\
\text { workers }\end{array}$ & $\begin{array}{l}\text { Open ended questions } \\
\text { for qualitative analysis }\end{array}$ & $\begin{array}{l}\text { Support from } \\
\text { peers and } \\
\text { organization }\end{array}$ & $\begin{array}{l}\text { Mental status } \\
\text { related to } \\
\text { emotions } \\
\text { perception }\end{array}$ & $\begin{array}{l}\text { The employees' emotional } \\
\text { reactions were elicited } \\
\text { from the perceived } \\
\text { organizational support, in } \\
\text { how the organization } \\
\text { cares for their wellbeing } \\
\text { and work contributions } \\
\text { and, in turn, influence the } \\
\text { psychological safety. } \\
\text { Anxiety, stress, unfairness, } \\
\text { inferiority and } \\
\text { vulnerability are triggered } \\
\text { by perceived }\end{array}$ \\
\hline $\begin{array}{l}\text { Al-Ghunaim } \\
\text { T. et al. [53] }\end{array}$ & $\begin{array}{l}141 / \mathrm{UK} / \\
\text { qualitative } \\
\text { analysis }\end{array}$ & Surgeons & $\begin{array}{c}\text { Qualitative analysis } \\
\text { through two } \\
\text { open-ended questions }\end{array}$ & $\begin{array}{l}\text { Changes in } \\
\text { workload and job } \\
\text { demand/Work } \\
\text { competence and } \\
\text { adequate training }\end{array}$ & $\begin{array}{l}\text { Stress and } \\
\text { burnout; fear } \\
\text { anxiety, loss } \\
\text { of motivation, } \\
\text { low mood. }\end{array}$ & $\begin{array}{l}\text { Surgeons' mental health } \\
\text { during COVID-19 } \\
\text { pandemic was affected by } \\
\text { substantial emotional and } \\
\text { psychological effects } \\
\text { particularly in relation to } \\
\text { fear and anxiety, loss of } \\
\text { motivation, low mood, } \\
\text { stress and burnout, } \\
\text { highlighting the urgent } \\
\text { need for workplace } \\
\text { support and mental } \\
\text { health interventions. }\end{array}$ \\
\hline
\end{tabular}


Table A1. Cont.

\begin{tabular}{|c|c|c|c|c|c|c|}
\hline Authors & $\begin{array}{c}\text { Sample/ } \\
\text { Country/ } \\
\text { Study Design }\end{array}$ & $\begin{array}{l}\text { Working } \\
\text { Population }\end{array}$ & Scale Used & $\begin{array}{c}\text { Intervention/ } \\
\text { Psychosocial } \\
\text { Risks Identified }\end{array}$ & $\begin{array}{c}\text { Mental } \\
\text { Outcomes }\end{array}$ & Main Results \\
\hline $\begin{array}{l}\text { Al-Mansour, } \\
\text { K. et al. [26] }\end{array}$ & $\begin{array}{c}\text { 1378/Saudi } \\
\text { Arabia/cross } \\
\text { sectional }\end{array}$ & $\begin{array}{c}\text { Physicians, } \\
\text { nurses, } \\
\text { other } \\
\text { health pro- } \\
\text { fessionals } \\
\text { and other } \\
\text { workers } \\
\text { who } \\
\text { worked in } \\
\text { the primary } \\
\text { healthcare } \\
\text { centers. }\end{array}$ & $\begin{array}{c}\text {-Perceived Stress Scale } \\
\text { (PSS) Rosenberg } \\
\text { Self-Esteem Scale } \\
\text { (RSES); } \\
\text { Multidimensional Scale } \\
\text { of Perceived Social } \\
\text { Support (MSPSS);-scale } \\
\text { for ambiguity at work. }\end{array}$ & $\begin{array}{l}\text { Support from } \\
\text { peers and } \\
\text { organization }\end{array}$ & Stress & $\begin{array}{l}\text { During the COVID-19 } \\
\text { pandemic, higher levels of } \\
\text { stress and role conflict } \\
\text { and ambiguity were } \\
\text { found among HCWs in } \\
\text { fever clinics than among } \\
\text { HCWs in regular primary } \\
\text { healthcare centers in } \\
\text { Saudi Arabia. Role } \\
\text { conflict and ambiguity, } \\
\text { social support and } \\
\text { self-esteem were found to } \\
\text { be major determinants of } \\
\text { stress among HCWs } \\
\text { during the pandemics. }\end{array}$ \\
\hline $\begin{array}{l}\text { Digby, R.et al. } \\
\text { [22] }\end{array}$ & $\begin{array}{c}\text { 321/Australia/ } \\
\text { qualitative } \\
\text { analysis }\end{array}$ & $\begin{array}{l}\text { Medical, } \\
\text { nursing, } \\
\text { allied } \\
\text { health and } \\
\text { non- } \\
\text { clinical } \\
\text { staff }\end{array}$ & $\begin{array}{c}\text { Qualitative: Free-text } \\
\text { questions }\end{array}$ & $\begin{array}{l}\text { Work competence } \\
\text { and adequate } \\
\text { training/Support } \\
\text { from peers and } \\
\text { organization }\end{array}$ & $\begin{array}{l}\text { Anxiety, } \\
\text { stress }\end{array}$ & $\begin{array}{l}\text { Healthcare staff need both } \\
\text { practical and } \\
\text { psychological support and } \\
\text { regular clear } \\
\text { communication to } \\
\text { minimize anxiety, } \\
\text { promote well-being, foster } \\
\text { resilience, and ensure that } \\
\text { they are in a strong } \\
\text { position to deal with the } \\
\text { health crisis }\end{array}$ \\
\hline $\begin{array}{l}\text { Dreher, A.et } \\
\text { al. [60] }\end{array}$ & $\begin{array}{l}\text { 2150/Germany/ } \\
\text { cross sectional }\end{array}$ & $\begin{array}{l}\text { Medical } \\
\text { assistants } \\
\text { (MA) }\end{array}$ & $\begin{array}{c}\text { Patient Health } \\
\text { Questionnaire (PHQ-2); } \\
\text { Generalized Anxiety } \\
\text { Disorder questionnaire } \\
\text { (GAD-2); questions on } \\
\text { socio-demographic data, } \\
\text { own contraction of } \\
\text { SARS-CoV-2, } \\
\text { contraction of } \\
\text { SARS-CoV-2 among } \\
\text { family, friends, and } \\
\text { colleagues, and } \\
\text { questions on attitudes, } \\
\text { stressors, and } \\
\text { work-related outcomes } \\
\text { during SARS-CoV-2 } \\
\text { pandemic. }\end{array}$ & $\begin{array}{c}\text { Support from } \\
\text { peers and organi- } \\
\text { zation/Work } \\
\text { competence and } \\
\text { adequate training }\end{array}$ & $\begin{array}{l}\text { Anxiety, } \\
\text { depression }\end{array}$ & $\begin{array}{c}\text { A low level of } \\
\text { preparedness and high } \\
\text { levels of uncertainty } \\
\text { affected MAs in Germany } \\
\text { regarding the } \\
\text { SARS-CoV-2 pandemic. } \\
\text { Major stressors were } \\
\text { uncertainty about the } \\
\text { temporal scope of the } \\
\text { pandemic, uncertainty } \\
\text { about how to act correctly, } \\
\text { a feeling of not being } \\
\text { allowed to let patients } \\
\text { down and uncertainty } \\
\text { about one's financial } \\
\text { situation. }\end{array}$ \\
\hline $\begin{array}{c}\text { Elshami, W. } \\
\text { et al. [59] }\end{array}$ & $\begin{array}{l}\text { 385/Middle East, } \\
\text { North Africa and } \\
\text { India/cross } \\
\text { sectional }\end{array}$ & $\begin{array}{l}\text { RWF } \\
\text { working at } \\
\text { hospitals } \\
\text { during the } \\
\text { pandemic, } \\
\text { such as ra- } \\
\text { diologists, } \\
\text { radiogra- } \\
\text { phers, } \\
\text { advanced } \\
\text { practition- } \\
\text { ers and } \\
\text { radiology } \\
\text { nurses }\end{array}$ & $\begin{array}{l}\text { The survey consisted of } \\
\text { four sections: } \\
\text { demographic } \\
\text { characteristics, } \\
\text { radiology professional } \\
\text { practice survey, the } \\
\text { Coronavirus Anxiety } \\
\text { Scale (CAS), and the } \\
\text { Fear of COVID-19 } \\
\text { Scale(FCe19S). }\end{array}$ & $\begin{array}{l}\text { Job insecurity and } \\
\text { financial } \\
\text { stress/Changes in } \\
\text { workload and job } \\
\text { demand/Work } \\
\text { competence and } \\
\text { adequate training }\end{array}$ & $\begin{array}{c}\text { Stress, } \\
\text { anxiety, fear }\end{array}$ & $\begin{array}{c}\text { Fear was associated with } \\
\text { workers younger than } 30 \\
\text { years of age and also with } \\
\text { temporary staff. } \\
\text { Nevertheless, anxiety } \\
\text { occurred completely } \\
\text { independently of gender, } \\
\text { age, experience, country, } \\
\text { working environment and } \\
\text { work status. Professional } \\
\text { support is needed to } \\
\text { reduce or prevent fear, } \\
\text { stress, and anxiety among } \\
\text { HCPs. }\end{array}$ \\
\hline
\end{tabular}


Table A1. Cont.

\begin{tabular}{|c|c|c|c|c|c|c|}
\hline Authors & $\begin{array}{c}\text { Sample/ } \\
\text { Country/ } \\
\text { Study Design }\end{array}$ & $\begin{array}{l}\text { Working } \\
\text { Population }\end{array}$ & Scale Used & $\begin{array}{c}\text { Intervention/ } \\
\text { Psychosocial } \\
\text { Risks Identified }\end{array}$ & $\begin{array}{c}\text { Mental } \\
\text { Outcomes }\end{array}$ & Main Results \\
\hline $\begin{array}{l}\text { Yang, Y. et al. } \\
{[51]}\end{array}$ & $\begin{array}{l}\text { 1208/China, } \\
\text { USA/cross } \\
\text { sectional }\end{array}$ & $\begin{array}{l}664 \text { doctors, } \\
246 \text { nurses }\end{array}$ & $\begin{array}{c}\text { DASS (Depression, } \\
\text { Anxiety, and Stress } \\
\text { Scale); PSS (Perceived } \\
\text { Social Support Scale) }\end{array}$ & $\begin{array}{l}\text { Changes in } \\
\text { workload and job } \\
\text { demand }\end{array}$ & $\begin{array}{l}\text { Anxiety, } \\
\text { depression, } \\
\text { stress }\end{array}$ & $\begin{array}{c}\text { Stress, anxiety, and } \\
\text { depression were } \\
\text { positively related to lower } \\
\text { levels of social support, } \\
\text { longer working hours, } \\
\text { discrimination experience } \\
\text { and workplace violence. } \\
\text { Stress, anxiety, and } \\
\text { depression were } \\
\text { positively related to lower } \\
\text { levels of social support, } \\
\text { longer working hours, } \\
\text { discrimination experience } \\
\text { and workplace violence. }\end{array}$ \\
\hline $\begin{array}{c}\text { Feeley, T. et al. } \\
\text { [52] }\end{array}$ & $\begin{array}{l}\text { 408/Ireland/cross } \\
\text { sectional } \\
\text { qualitative design }\end{array}$ & $\begin{array}{l}\text { Intensive } \\
\text { care unit } \\
\text { (ICU) staff }\end{array}$ & Open questions & $\begin{array}{l}\text { Changes in } \\
\text { workload and job } \\
\text { demand/Job } \\
\text { insecurity and } \\
\text { financial } \\
\text { stress/Home- } \\
\text { work interface } \\
\text { and balance }\end{array}$ & $\begin{array}{l}\text { Occupational } \\
\text { stress }\end{array}$ & $\begin{array}{l}\text { The home, work and } \\
\text { social environments, the } \\
\text { home-work interface and } \\
\text { uncertainty about the } \\
\text { future were the major } \\
\text { themes retrieved. } \\
\text { The work } \\
\text { environment-team } \\
\text { structure, senior staff } \\
\text { guidance, social } \\
\text { communication, colleague } \\
\text { support, altered role, high } \\
\text { workload-dictated the } \\
\text { emotional and } \\
\text { psychological responses } \\
\text { of healthcare staff. }\end{array}$ \\
\hline $\begin{array}{l}\text { Gul, S. et al. } \\
{[63]}\end{array}$ & $\begin{array}{l}\text { 192/Turkey/cross } \\
\text { sectional }\end{array}$ & $\begin{array}{l}\text { Operating } \\
\text { rooms } \\
\text { nurses }\end{array}$ & $\begin{array}{c}\text { Beck Anxiety inventory } \\
\text { (BAI) }\end{array}$ & $\begin{array}{l}\text { Support from } \\
\text { peers and organi- } \\
\text { zation/Changes } \\
\text { in workload and } \\
\text { job demand }\end{array}$ & Anxiety & $\begin{array}{l}\text { Nurses experienced } \\
\text { moderate levels of anxiety } \\
\text { as they are inexperienced } \\
\text { and must work with } \\
\text { patients who pose a } \\
\text { serious level of risk; they } \\
\text { should be trained in } \\
\text { critical patient care in } \\
\text { order to reduce their } \\
\text { anxiety levels. }\end{array}$ \\
\hline $\begin{array}{l}\text { Havaei, F. } \\
\text { et al. [33] }\end{array}$ & $\begin{array}{l}\text { 3676/Canada/cross } \\
\text { sectional }\end{array}$ & Nurses & $\begin{array}{l}\text { Post-traumatic Stress } \\
\text { Symptoms-14 (PTSS-14); } \\
\text { Generalized Anxiety } \\
\text { Disorder-7 (GAD-7); } \\
\text { Patient Health } \\
\text { Questionnaire-9 } \\
\text { (PHQ-9); EE subscale of } \\
\text { the Maslach Burnout } \\
\text { Inventory; Human } \\
\text { Services Survey } \\
\text { (MBI-HSS) }\end{array}$ & $\begin{array}{l}\text { Support from } \\
\text { peers and } \\
\text { organization }\end{array}$ & $\begin{array}{l}\text { Anxiety, } \\
\text { PTSD, } \\
\text { depression, } \\
\text { burnout }\end{array}$ & $\begin{array}{l}\text { Negative ratings of } \\
\text { workplace relations, } \\
\text { organizational support, } \\
\text { organizational } \\
\text { preparedness, workplace } \\
\text { safety, and access to } \\
\text { supplies and resources } \\
\text { were associated with } \\
\text { higher scores on all of the } \\
\text { adverse mental health } \\
\text { outcomes. Better } \\
\text { workplace policies and } \\
\text { practices are urgently } \\
\text { required to prevent and } \\
\text { mitigate nurses' } \\
\text { suboptimal work } \\
\text { conditions. }\end{array}$ \\
\hline
\end{tabular}


Table A1. Cont.

\begin{tabular}{|c|c|c|c|c|c|c|}
\hline Authors & $\begin{array}{c}\text { Sample/ } \\
\text { Country/ } \\
\text { Study Design }\end{array}$ & $\begin{array}{l}\text { Working } \\
\text { Population }\end{array}$ & Scale Used & $\begin{array}{c}\text { Intervention/ } \\
\text { Psychosocial } \\
\text { Risks Identified }\end{array}$ & $\begin{array}{l}\text { Mental } \\
\text { Outcomes }\end{array}$ & Main Results \\
\hline $\begin{array}{l}\text { Halley, M.C. } \\
\text { et al. [49] }\end{array}$ & $\begin{array}{l}\text { 1806/USA/ } \\
\text { qualitative } \\
\text { analysis }\end{array}$ & $\begin{array}{l}\text { Physician } \\
\text { mothers }\end{array}$ & Qualitative approach & $\begin{array}{l}\text { Support from } \\
\text { peers and } \\
\text { organization/Home- } \\
\text { work interface } \\
\text { and balance/Job } \\
\text { insecurity and } \\
\text { financial stress }\end{array}$ & Stress & $\begin{array}{l}\text { Leaders within healthcare } \\
\text { organizations and the } \\
\text { government need a deep } \\
\text { understanding of the } \\
\text { physician mothers' } \\
\text { challenges in order to } \\
\text { ensure robust public } \\
\text { health policies, adequate } \\
\text { equipment for personal } \\
\text { safety and optimal patient } \\
\text { care, and support to meet } \\
\text { basic personal financial } \\
\text { and family needs. }\end{array}$ \\
\hline $\begin{array}{l}\text { Hu, J. et al. } \\
\text { [34] }\end{array}$ & $\begin{array}{c}\text { 1:163/2:282/3:210/ } \\
\text { China/USA/cross } \\
\text { sectional }\end{array}$ & $\begin{array}{c}1: \\
\text { employees } \\
\text { of an infor- } \\
\text { mation } \\
\text { technology } \\
\text { company } \\
\text { 2: } \\
\text { Amazon's } \\
\text { Mechanical } \\
\text { Turk } \\
\text { 3: } \\
\text { Amazon's } \\
\text { Mechanical } \\
\text { Turk }\end{array}$ & Ad hoc questionnaires & $\begin{array}{l}\text { Support from } \\
\text { peers and } \\
\text { organization }\end{array}$ & $\begin{array}{l}\text { Anxiety } \\
\text { symptoms }\end{array}$ & $\begin{array}{l}\text { COVID-19-triggered } \\
\text { mortality salience } \\
\text { increases state anxiety. } \\
\text { Mortality salience not } \\
\text { only triggers anxiety } \\
\text { about own deaths but also } \\
\text { generates tremendous } \\
\text { overall anxiety. Servant } \\
\text { leaders who keep } \\
\text { employees' well-being } \\
\text { paramount and model } \\
\text { compassion can help } \\
\text { anxious employees stay } \\
\text { engaged at work and help } \\
\text { the broader community. }\end{array}$ \\
\hline $\begin{array}{l}\text { Ingusci, E. } \\
\text { et al. [57]. }\end{array}$ & $530 /$ Italy/ & $\begin{array}{l}\text { Remote } \\
\text { workers }\end{array}$ & $\begin{array}{l}\text { Validated scales for } \\
\text { workload, job crafting } \\
\text { and behavioral stress }\end{array}$ & $\begin{array}{l}\text { Changes in } \\
\text { workload and job } \\
\text { demand/Work } \\
\text { competence and } \\
\text { adequate training }\end{array}$ & $\begin{array}{l}\text { Occupational } \\
\text { Stress }\end{array}$ & $\begin{array}{l}\text { The direct effect between } \\
\text { work overload and } \\
\text { behavioral stress was } \\
\text { positive; the indirect, } \\
\text { negative effect through } \\
\text { the mediation of job } \\
\text { crafting was also } \\
\text { significant Job crafting can } \\
\text { play a crucial role as a } \\
\text { protective factor } \\
\text { supporting the activation } \\
\text { and adjustment of } \\
\text { suitable resources; these } \\
\text { resources can be useful to } \\
\text { deal with the negative } \\
\text { effects of work overload, } \\
\text { particularly under the } \\
\text { condition of heavy remote } \\
\text { working and use of } \\
\text { technologies. }\end{array}$ \\
\hline $\begin{array}{l}\text { Mekonen, E. } \\
\text { et al. [58] }\end{array}$ & $\begin{array}{l}\text { 302/Ethiopia/cross } \\
\text { sectional }\end{array}$ & Nurses & DASS-21 & $\begin{array}{l}\text { Changes in } \\
\text { workload and job } \\
\text { demand/Work } \\
\text { competence and } \\
\text { adequate training }\end{array}$ & $\begin{array}{l}\text { Anxiety, } \\
\text { depression, } \\
\text { and stress }\end{array}$ & $\begin{array}{l}\text { Workload, taking training, } \\
\text { having a guideline, } \\
\text { adequate protective } \\
\text { equipment, having } \\
\text { children, fear of infecting } \\
\text { family members, feedback } \\
\text { from families and friends } \\
\text { are significantly } \\
\text { associated with anxiety, } \\
\text { depression and stress. }\end{array}$ \\
\hline
\end{tabular}


Table A1. Cont.

\begin{tabular}{|c|c|c|c|c|c|c|}
\hline Authors & $\begin{array}{c}\text { Sample/ } \\
\text { Country/ } \\
\text { Study Design }\end{array}$ & $\begin{array}{l}\text { Working } \\
\text { Population }\end{array}$ & Scale Used & $\begin{array}{c}\text { Intervention/ } \\
\text { Psychosocial } \\
\text { Risks Identified }\end{array}$ & $\begin{array}{c}\text { Mental } \\
\text { Outcomes }\end{array}$ & Main Results \\
\hline $\begin{array}{l}\text { Al-Jumaili, } \\
\text { A.A. et al. } \\
\text { [27] }\end{array}$ & $\begin{array}{c}430 / \text { Iraq/cross } \\
\text { sectional }\end{array}$ & $\begin{array}{l}\text { Healthcare } \\
\text { providers } \\
\text { (HCPs) }\end{array}$ & $\begin{array}{c}\text { Adopted items of } \\
\text { surveys used in } \\
\text { previous studies of } \\
\text { Severe Acute } \\
\text { Respiratory Syndrome } \\
\text { (SARS) and Avian } \\
\text { Influenza Outbreak }\end{array}$ & $\begin{array}{l}\text { Support from } \\
\text { peers and } \\
\text { organization }\end{array}$ & Stress & $\begin{array}{c}\text { Working during } \\
\text { COVID-19 pandemic has } \\
\text { several negative impacts } \\
\text { on HCPs including mental } \\
\text { and physical health and } \\
\text { an overwhelming work } \\
\text { environment. Thus, social } \\
\text { and emotional support is } \\
\text { needed to help HCPs to } \\
\text { cope with such stressful } \\
\text { conditions }\end{array}$ \\
\hline $\begin{array}{c}\text { Mo, Y., et al. } \\
{[23]}\end{array}$ & $\begin{array}{c}\text { 200/China/cross } \\
\text { sectional }\end{array}$ & Nurses & $\begin{array}{c}\text { Self-rating Anxiety } \\
\text { Scale (SAS); Stress } \\
\text { Overload Scale (SOS); } \\
\text { General Self-efficacy } \\
\text { Scale (GSES) }\end{array}$ & $\begin{array}{l}\text { Support from } \\
\text { peers and } \\
\text { organization }\end{array}$ & $\begin{array}{l}\text { Anxiety, } \\
\text { stress, } \\
\text { self-efficacy }\end{array}$ & $\begin{array}{l}\text { Nurses' mental health } \\
\text { were affected by, sleep } \\
\text { status, stress and } \\
\text { self-efficacy. Work stress } \\
\text { and self-efficacy were } \\
\text { closely correlated with } \\
\text { anxiety. Social support } \\
\text { plays an important role in } \\
\text { alleviating mental stress. } \\
\text { Self-efficacy is negatively } \\
\text { correlated with anxiety. }\end{array}$ \\
\hline $\begin{array}{l}\text { Nguyen, P. } \\
\text { et al. [62] }\end{array}$ & $\begin{array}{l}761 / \text { Vietnam/ } \\
\text { cross sectional }\end{array}$ & $\begin{array}{l}\text { Healthcare } \\
\text { workers }\end{array}$ & $\begin{array}{c}\text { Impact of Event } \\
\text { Scale-Revised (IES-R) }\end{array}$ & $\begin{array}{c}\text { Changes in } \\
\text { workload and job } \\
\text { demand }\end{array}$ & Stress & $\begin{array}{l}\text { It was found that there } \\
\text { was a higher risk of } \\
\text { having stress among } \\
\text { HCWs who were at the } \\
\text { frontline, since they } \\
\text { perceived their health } \\
\text { status as worse as } \\
\text { compared with that before } \\
\text { the pandemic. Most } \\
\text { HCWs were worried } \\
\text { about being a potential } \\
\text { source of infection to their } \\
\text { families. }\end{array}$ \\
\hline $\begin{array}{l}\text { Norful, A. } \\
\text { [28] }\end{array}$ & $\begin{array}{l}\text { 55/USA/ } \\
\text { qualitative } \\
\text { analysis }\end{array}$ & $\begin{array}{l}\text { Healthcare } \\
\text { workers }\end{array}$ & Qualitative interviews & $\begin{array}{l}\text { Support from } \\
\text { peers and } \\
\text { organization }\end{array}$ & $\begin{array}{l}\text { Burnout, } \\
\text { anxiety, sleep } \\
\text { disturbance, } \\
\text { stress }\end{array}$ & $\begin{array}{l}\text { Uncertainty of COVID-19 } \\
\text { practice guidelines, lack of } \\
\text { resources, and risk of } \\
\text { transmission to loved } \\
\text { ones at home were the } \\
\text { primary drivers behind } \\
\text { stress. Further, anxiety, } \\
\text { physical exhaustion, and } \\
\text { sleep disturbances were } \\
\text { the predominant } \\
\text { manifestations of stress } \\
\text { experienced by } \\
\text { participants. Psychosocial } \\
\text { support and increased } \\
\text { teamwork across } \\
\text { disciplines emerged as a } \\
\text { significant mitigator of } \\
\text { stress, yielding less } \\
\text { perceived burnout and } \\
\text { improved clinician } \\
\text { wellbeing. }\end{array}$ \\
\hline
\end{tabular}


Table A1. Cont.

\begin{tabular}{|c|c|c|c|c|c|c|}
\hline Authors & $\begin{array}{c}\text { Sample/ } \\
\text { Country/ } \\
\text { Study Design }\end{array}$ & $\begin{array}{l}\text { Working } \\
\text { Population }\end{array}$ & Scale Used & $\begin{array}{c}\text { Intervention/ } \\
\text { Psychosocial } \\
\text { Risks Identified }\end{array}$ & $\begin{array}{c}\text { Mental } \\
\text { Outcomes }\end{array}$ & Main Results \\
\hline $\begin{array}{l}\text { Rodriguez- } \\
\text { Lopez, A.M. } \\
\text { [39] }\end{array}$ & $\begin{array}{c}\text { 360/Spain/cross } \\
\text { sectional }\end{array}$ & $\begin{array}{l}\text { Fashion } \\
\text { Retailing } \\
\text { Workers }\end{array}$ & $\begin{array}{c}\text { CarMen-Q Mental } \\
\text { workload questionnaire } \\
\text { (Cognitive Demands, } \\
\text { Temporal Demands, } \\
\text { Emotional Demands, } \\
\text { Performance Demands); } \\
\text { MBI Burnout Syndrome } \\
\text { Inventory (Emotional } \\
\text { Exhaustion, } \\
\text { Depersonalization, } \\
\text { Personal } \\
\text { Accomplishment); } \\
\text { Perception of COVID-19 }\end{array}$ & $\begin{array}{l}\text { Changes in } \\
\text { workload and job } \\
\text { demand/Job } \\
\text { insecurity and } \\
\text { financial stress }\end{array}$ & Burnout & $\begin{array}{l}\text { Participants exhibited } \\
\text { deep concern about the } \\
\text { COVID-19 pandemic and } \\
\text { its influence in the } \\
\text { workplace. } \\
\text { Environmental changes, } \\
\text { work overload, somatic } \\
\text { symptoms, insomnia, } \\
\text { negative job expectations, } \\
\text { and uncertainty } \\
\text { constituted significant } \\
\text { mental workload } \\
\text { predictors. Insomnia, } \\
\text { somatic symptoms, and } \\
\text { negative job expectations } \\
\text { constituted significant } \\
\text { predictors for burnout. }\end{array}$ \\
\hline $\begin{array}{l}\text { Tokac, U. } \\
\text { et al. [66] }\end{array}$ & $\begin{array}{c}\text { 83/USA/cross } \\
\text { sectional }\end{array}$ & Nurses & $\begin{array}{c}\text { Patient Health } \\
\text { Questionnaire (PHQ-9); } \\
\text { Generalized Anxiety } \\
\text { Disorder (GAD-7) Scale; } \\
\text { Insomnia Severity Index } \\
\text { (ISI); Impact of Event } \\
\text { Scale-Revised (IES-R); } \\
\text { Compassion Fatigue } \\
\text { and Satisfaction } \\
\text { Self-Test (CFS); Work } \\
\text { Productivity and } \\
\text { Activity Impairment } \\
\text { Question- } \\
\text { naire(WPAI:GH) }\end{array}$ & $\begin{array}{c}\text { Work competence } \\
\text { and adequate } \\
\text { training }\end{array}$ & $\begin{array}{l}\text { Anxiety, } \\
\text { depression, } \\
\text { burnout, } \\
\text { avoidance } \\
\text { level }\end{array}$ & $\begin{array}{l}\text { Nurses' work impairment } \\
\text { decreased with greater } \\
\text { years of nursing } \\
\text { experience and increased } \\
\text { with higher anxiety, } \\
\text { depression, burnout and } \\
\text { avoidance levels. }\end{array}$ \\
\hline $\begin{array}{l}\text { Coulombe, S. } \\
\text { et al. [29] }\end{array}$ & $\begin{array}{l}\text { 1122/Canada/ } \\
\text { cross sectional }\end{array}$ & $\begin{array}{l}\text { Workers } \\
\text { not further } \\
\text { specified }\end{array}$ & $\begin{array}{l}\text { Perceived Stress Scale } \\
\text { (PSS) Patient Crisis; } \\
\text { Disaster Preparedness } \\
\text { Scale; Depression and } \\
\text { Anxiety (PHQ-4); ad } \\
\text { hoc questionnaires }\end{array}$ & $\begin{array}{c}\text { Job insecurity and } \\
\text { financial } \\
\text { stress/Support } \\
\text { from peers and } \\
\text { organization }\end{array}$ & $\begin{array}{l}\text { Distress and } \\
\text { stress }\end{array}$ & $\begin{array}{l}\text { COVID-19 crisis } \\
\text { encompasses several } \\
\text { stressors related to the } \\
\text { virus as well as to its } \\
\text { impact on one's social, } \\
\text { occupational, and } \\
\text { financial situation, putting } \\
\text { workers at risk of lower } \\
\text { wellbeing. }\end{array}$ \\
\hline $\begin{array}{l}\text { Moreno- } \\
\text { Jiménez, J. } \\
\text { et al. [61] }\end{array}$ & $\begin{array}{c}\text { 221/Spain/cross } \\
\text { sectional }\end{array}$ & $\begin{array}{l}\text { Health pro- } \\
\text { fessionals }\end{array}$ & $\begin{array}{c}\text { Nursing Burnout Scale } \\
\text { (NBS), Occupational } \\
\text { Hardiness } \\
\text { Questionnaire, Short } \\
\text { Burnout Questionnaire, } \\
\text { Secondary Traumatic } \\
\text { Stress Scale, ad hoc } \\
\text { questionnaires }\end{array}$ & $\begin{array}{l}\text { Changes in } \\
\text { workload and job } \\
\text { demand }\end{array}$ & $\begin{array}{l}\text { Emotional } \\
\text { exhaustion } \\
\text { and } \\
\text { secondary } \\
\text { traumatic } \\
\text { stress }\end{array}$ & $\begin{array}{l}\text { The lack of human } \\
\text { resources predicted } \\
\text { emotional exhaustion } \\
\text { through the workload and } \\
\text { secondary traumatic } \\
\text { stress through fear of } \\
\text { contagion, contact with } \\
\text { death/suffering, and } \\
\text { workload. }\end{array}$ \\
\hline
\end{tabular}

\section{References}

1. Giorgi, G.; Lecca, L.I.; Alessio, F.; Finstad, G.L.; Bondanini, G.; Lulli, L.G.; Arcangeli, G.; Mucci, N. COVID-19-Related Mental Health Effects in the Workplace: A Narrative Review. Int. J. Environ. Res. Public Health 2020, 17, 7857. [CrossRef]

2. Sheraton, M.; Deo, N.; Dutt, T.; Surani, S.; Hall-Flavin, D.; Kashyap, R. Psychological Effects of the COVID-19 Pandemic on Healthcare Workers Globally: A Systematic Review. Psychiatry Res. 2020, 292, 113360. [CrossRef] [PubMed]

3. Sigahi, T.F.A.C.; Kawasaki, B.C.; Bolis, I.; Morioka, S.N. A Systematic Review on the Impacts of COVID-19 on Work: Contributions and a Path Forward from the Perspectives of Ergonomics and Psychodynamics of Work. Hum. Factors Ergon. Manuf. 2021, 31, 375-388. [CrossRef] [PubMed]

4. $\quad$ Sanghera, J.; Pattani, N.; Hashmi, Y.; Varley, K.F.; Cheruvu, M.S.; Bradley, A.; Burke, J.R. The Impact of SARS-CoV-2 on the Mental Health of Healthcare Workers in a Hospital Setting_A Systematic Review. J. Occup. Health 2020, 62, e12175. Available online: https:/ / onlinelibrary.wiley.com/doi/10.1002/1348-9585.12175 (accessed on 6 September 2021). [CrossRef] 
5. Baldassarre, A.; Giorgi, G.; Alessio, F.; Lulli, L.G.; Arcangeli, G.; Mucci, N. Stigma and Discrimination (SAD) at the Time of the SARS-CoV-2 Pandemic. Int. J. Environ. Res. Public Health 2020, 17, 6341. [CrossRef] [PubMed]

6. Sanchez-Gomez, M.; Giorgi, G.; Finstad, G.L.; Urbini, F.; Foti, G.; Mucci, N.; Zaffina, S.; León-Perez, J.M. COVID-19 Pandemic as a Traumatic Event and Its Associations with Fear and Mental Health: A Cognitive-Activation Approach. Int. J. Environ. Res. Public Health 2021, 18, 7422. [CrossRef] [PubMed]

7. De Pablo, G.S.; Vaquerizo-Serrano, J.; Catalan, A.; Arango, C.; Moreno, C.; Ferre, F.; Shin, J.I.; Sullivan, S.; Brondino, N.; Solmi, M.; et al. Impact of Coronavirus Syndromes on Physical and Mental Health of Health Care Workers: Systematic Review and Meta-Analysis. J. Affect. Disord. 2020, 275, 48-57. [CrossRef] [PubMed]

8. Kisely, S.; Warren, N.; McMahon, L.; Dalais, C.; Henry, I.; Siskind, D. Occurrence, Prevention, and Management of the Psychological Effects of Emerging Virus Outbreaks on Healthcare Workers: Rapid Review and Meta-Analysis. BMJ 2020, 369 , m1642. [CrossRef] [PubMed]

9. Mhango, M.; Dzobo, M.; Chitungo, I.; Dzinamarira, T. COVID-19 Risk Factors Among Health Workers: A Rapid Review. Saf. Health Work 2020, 11, 262-265. [CrossRef]

10. Stansfeld, S.; Candy, B. Psychosocial Work Environment and Mental Health-A Meta-Analytic Review. Scand. J. Work Environ. Health 2006, 32, 443-462. [CrossRef]

11. Posel, D.; Oyenubi, A.; Kollamparambil, U. Job Loss and Mental Health during the COVID-19 Lockdown: Evidence from South Africa. PLoS ONE 2021, 16, e0249352. [CrossRef] [PubMed]

12. ILO Monitor: COVID-19 and the World of Work. 7th Edition. Available online: http://www.ilo.org/global/topics/coronavirus/ impacts-and-responses/WCMS_767028/lang--en/index.htm (accessed on 6 September 2021).

13. Barone Gibbs, B.; Kline, C.E.; Huber, K.A.; Paley, J.L.; Perera, S. COVID-19 Shelter-at-Home and Work, Lifestyle and Well-Being in Desk Workers. Occup. Med. 2021, 71, 86-94. [CrossRef] [PubMed]

14. Galanti, T.; Guidetti, G.; Mazzei, E.; Zappalà, S.; Toscano, F. Work from Home during the COVID-19 Outbreak: The Impact on Employees' Remote Work Productivity, Engagement, and Stress. J. Occup. Environ. Med. 2021, 63, e426-e432. [CrossRef]

15. Preparing for the next Pandemic. Nat. Med. 2021, 27, 357. Available online: https://doi.org/10.1038/s41591-021-01291-z (accessed on 6 September 2021).

16. Page, M.J.; McKenzie, J.E.; Bossuyt, P.M.; Boutron, I.; Hoffmann, T.C.; Mulrow, C.D.; Shamseer, L.; Tetzlaff, J.M.; Akl, E.A.; Brennan, S.E.; et al. The PRISMA 2020 Statement: An Updated Guideline for Reporting Systematic Reviews. BMJ 2021, 372 , n71. [CrossRef] [PubMed]

17. Aguiar-Quintana, T.; Nguyen, T.H.H.; Araujo-Cabrera, Y.; Sanabria-Díaz, J.M. Do Job Insecurity, Anxiety and Depression Caused by the COVID-19 Pandemic Influence Hotel Employees' Self-Rated Task Performance? The Moderating Role of Employee Resilience. Int. J. Hosp. Manag. 2021, 94, 102868. [CrossRef]

18. Zhou, T.; Guan, R.; Sun, L. Perceived Organizational Support and PTSD Symptoms of Frontline Healthcare Workers in the Outbreak of COVID-19 in Wuhan: The Mediating Effects of Self-Efficacy and Coping Strategies. Appl. Psychol. Health Well-Being 2021, 13, 745-760. [CrossRef]

19. Zhang, J.; Wang, Y.; Xu, J.; You, H.; Li, Y.; Liang, Y.; Li, S.; Ma, L.; Lau, J.T.-F.; Hao, Y.; et al. Prevalence of Mental Health Problems and Associated Factors among Front-Line Public Health Workers during the COVID-19 Pandemic in China: An Effort-Reward Imbalance Model-Informed Study. BMC Psychol. 2021, 9, 55. [CrossRef] [PubMed]

20. Khajuria, A.; Tomaszewski, W.; Liu, Z.; Chen, J.-H.; Mehdian, R.; Fleming, S.; Vig, S.; Crawford, M.J. Workplace Factors Associated with Mental Health of Healthcare Workers during the COVID-19 Pandemic: An International Cross-Sectional Study. BMC Health Serv. Res. 2021, 21, 262. [CrossRef] [PubMed]

21. Gilleen, J.; Santaolalla, A.; Valdearenas, L.; Salice, C.; Fusté, M. Impact of the COVID-19 Pandemic on the Mental Health and Well-Being of UK Healthcare Workers. BJPsych Open 2021, 7, e88. [CrossRef] [PubMed]

22. Escudero-Castillo, I.; Mato-Díaz, F.J.; Rodriguez-Alvarez, A. Furloughs, Teleworking and Other Work Situations during the COVID-19 Lockdown: Impact on Mental Well-Being. Int. J. Environ. Res. Public Health 2021, 18, 2898. [CrossRef] [PubMed]

23. Babore, A.; Lombardi, L.; Viceconti, M.L.; Pignataro, S.; Marino, V.; Crudele, M.; Candelori, C.; Bramanti, S.M.; Trumello, C. Psychological Effects of the COVID-2019 Pandemic: Perceived Stress and Coping Strategies among Healthcare Professionals. Psychiatry Res. 2020, 293, 113366. [CrossRef] [PubMed]

24. Bulińska-Stangrecka, H.; Bagieńska, A. The Role of Employee Relations in Shaping Job Satisfaction as an Element Promoting Positive Mental Health at Work in the Era of COVID-19. Int. J. Environ. Res. Public Health 2021, 18, 1903. [CrossRef]

25. Afulani, P.A.; Gyamerah, A.O.; Nutor, J.J.; Laar, A.; Aborigo, R.A.; Malechi, H.; Sterling, M.; Awoonor-Williams, J.K. Inadequate Preparedness for Response to COVID-19 Is Associated with Stress and Burnout among Healthcare Workers in Ghana. PLoS ONE 2021, 16, e0250294. [CrossRef] [PubMed]

26. Charoensukmongkol, P.; Phungsoonthorn, T. The Effectiveness of Supervisor Support in Lessening Perceived Uncertainties and Emotional Exhaustion of University Employees during the COVID-19 Crisis: The Constraining Role of Organizational Intransigence. J. Gen. Psychol. 2020, 148, 431-450. [CrossRef]

27. Cipolotti, L.; Chan, E.; Murphy, P.; van Harskamp, N.; Foley, J.A. Factors Contributing to the Distress, Concerns, and Needs of UK Neuroscience Health Care Workers during the COVID-19 Pandemic. Psychol. Psychother. 2021, 94 (Suppl. 2), 536-543. [CrossRef]

28. Elbay, R.Y.; Kurtulmuş, A.; Arpacioğlu, S.; Karadere, E. Depression, Anxiety, Stress Levels of Physicians and Associated Factors in COVID-19 Pandemics. Psychiatry Res. 2020, 290, 113130. [CrossRef] [PubMed] 
29. Gómez-Galán, J.; Lázaro-Pérez, C.; Martínez-López, J.Á.; Fernández-Martínez, M.D.M. Burnout in Spanish Security Forces during the COVID-19 Pandemic. Int. J. Environ. Res. Public Health 2020, 17, 8790. [CrossRef] [PubMed]

30. Hines, S.E.; Chin, K.H.; Glick, D.R.; Wickwire, E.M. Trends in Moral Injury, Distress, and Resilience Factors among Healthcare Workers at the Beginning of the COVID-19 Pandemic. Int. J. Environ. Res. Public Health 2021, 18, 488. [CrossRef] [PubMed]

31. Kannampallil, T.G.; Goss, C.W.; Evanoff, B.A.; Strickland, J.R.; McAlister, R.P.; Duncan, J. Exposure to COVID-19 Patients Increases Physician Trainee Stress and Burnout. PLoS ONE 2020, 15, e0237301. [CrossRef]

32. Labrague, L.J.; De Los Santos, J.A.A. COVID-19 Anxiety among Front-Line Nurses: Predictive Role of Organisational Support, Personal Resilience and Social Support. J. Nurs. Manag. 2020, 28, 1653-1661. [CrossRef]

33. Magnavita, N.; Soave, P.M.; Ricciardi, W.; Antonelli, M. Occupational Stress and Mental Health among Anesthetists during the COVID-19 Pandemic. Int. J. Environ. Res. Public Health 2020, 17, 8245. [CrossRef] [PubMed]

34. Manzano García, G.; Ayala Calvo, J.C. The Threat of COVID-19 and Its Influence on Nursing Staff Burnout. J. Adv. Nurs. 2021, 77, 832-844. [CrossRef]

35. Marco, C.A.; Larkin, G.L.; Feeser, V.R.; Monti, J.E.; Vearrier, L. For the ACEP Ethics Committee. Post-Traumatic Stress and Stress Disorders during the COVID-19 Pandemic: Survey of Emergency Physicians. JACEP Open 2020, 1, 1594-1601. [CrossRef] [PubMed]

36. Mattila, E.; Peltokoski, J.; Neva, M.H.; Kaunonen, M.; Helminen, M.; Parkkila, A.-K. COVID-19: Anxiety among Hospital Staff and Associated Factors. Ann. Med. 2021, 53, 237-246. [CrossRef]

37. Moretti, A.; Menna, F.; Aulicino, M.; Paoletta, M.; Liguori, S.; Iolascon, G. Characterization of Home Working Population during COVID-19 Emergency: A Cross-Sectional Analysis. Int. J. Environ. Res. Public Health 2020, 17, 6284. [CrossRef] [PubMed]

38. Morgantini, L.A.; Naha, U.; Wang, H.; Francavilla, S.; Acar, Ö.; Flores, J.M.; Crivellaro, S.; Moreira, D.; Abern, M.; Eklund, M.; et al. Factors Contributing to Healthcare Professional Burnout during the COVID-19 Pandemic: A Rapid Turnaround Global Survey. PLoS ONE 2020, 15, e0238217. [CrossRef] [PubMed]

39. Portoghese, I.; Meloni, F.; Galletta, M.; Piras, I.; D'Aloja, E.; Finco, G.; Campagna, M. Concerns, Perceived Impact, Preparedness in Coronavirus Disease (COVID-19) Pandemic and Health Outcomes among Italian Physicians: A Cross-Sectional Study. J. Prim. Care Community Health 2021, 12, 21501327211000244. [CrossRef]

40. Soto-Rubio, A.; Giménez-Espert, M.D.C.; Prado-Gascó, V. Effect of Emotional Intelligence and Psychosocial Risks on Burnout, Job Satisfaction, and Nurses' Health during the COVID-19 Pandemic. Int. J. Environ. Res. Public Health 2020, 17, 7998. [CrossRef]

41. Tušl, M.; Brauchli, R.; Kerksieck, P.; Bauer, G.F. Impact of the COVID-19 Crisis on Work and Private Life, Mental Well-Being and Self-Rated Health in German and Swiss Employees: A Cross-Sectional Online Survey. BMC Public Health 2021, 21, 741. [CrossRef] [PubMed]

42. Yang, Y.; Li, Y.; An, Y.; Zhao, Y.-J.; Zhang, L.; Cheung, T.; Hall, B.J.; Ungvari, G.S.; An, F.-R.; Xiang, Y.-T. Workplace Violence Against Chinese Frontline Clinicians During the COVID-19 Pandemic and Its Associations with Demographic and Clinical Characteristics and Quality of Life: A Structural Equation Modeling Investigation. Front. Psychiatry 2021, 12, 649989. [CrossRef] [PubMed]

43. Zandi, G.; Shahzad, I.; Farrukh, M.; Kot, S. Supporting Role of Society and Firms to COVID-19 Management among Medical Practitioners. Int. J. Environ. Res. Public Health 2020, 17, 7961. [CrossRef]

44. Zerbini, G.; Ebigbo, A.; Reicherts, P.; Kunz, M.; Messman, H. Psychosocial Burden of Healthcare Professionals in Times of COVID-19-A Survey Conducted at the University Hospital Augsburg. Ger. Med. Sci. 2020, 18, Doc05. [CrossRef]

45. Lee, H. Changes in Workplace Practices during the COVID-19 Pandemic: The Roles of Emotion, Psychological Safety and Organisation Support. J. Organ. Eff. People Perform. 2021, 8, 97-128. [CrossRef]

46. Al-Ghunaim, T.A.; Johnson, J.; Biyani, C.S.; O'Connor, D. Psychological and Occupational Impact of the COVID-19 Pandemic on UK Surgeons: A Qualitative Investigation. BMJ Open 2021, 11, e045699. [CrossRef] [PubMed]

47. Al-Mansour, K.; Alfuzan, A.; Alsarheed, D.; Alenezi, M.; Abogazalah, F. Work-Related Challenges among Primary Health Centers Workers during COVID-19 in Saudi Arabia. Int. J. Environ. Res. Public Health 2021, 18, 1898. [CrossRef]

48. Digby, R.; Winton-Brown, T.; Finlayson, F.; Dobson, H.; Bucknall, T. Hospital Staff Well-Being during the First Wave of COVID-19: Staff Perspectives. Int. J. Ment. Health Nurs. 2021, 30, 440-450. [CrossRef] [PubMed]

49. Dreher, A.; Pietrowsky, R.; Loerbroks, A. Pandemic-Related Attitudes, Stressors and Work Outcomes among Medical Assistants during the SARS-CoV-2 ("Coronavirus") Pandemic in Germany: A Cross-Sectional Study. PLoS ONE 2021, 16, e0245473. [CrossRef]

50. Elshami, W.; Akudjedu, T.N.; Abuzaid, M.; David, L.R.; Tekin, H.O.; Cavli, B.; Issa, B. The Radiology Workforce's Response to the COVID-19 Pandemic in the Middle East, North Africa and India. Radiography 2021, 27, 360-368. [CrossRef] [PubMed]

51. Yang, Y.; Lu, L.; Chen, T.; Ye, S.; Kelifa, M.O.; Cao, N.; Zhang, Q.; Liang, T.; Wang, W. Healthcare Worker's Mental Health and Their Associated Predictors during the Epidemic Peak of COVID-19. Psychol. Res. Behav. Manag. 2021, 14, 221-231. [CrossRef]

52. Feeley, T.; Ffrench-O'Carroll, R.; Tan, M.H.; Magner, C.; L'Estrange, K.; O’Rathallaigh, E.; Whelan, S.; Lyons, B.; O'Connor, E. A Model for Occupational Stress amongst Paediatric and Adult Critical Care Staff during COVID-19 Pandemic. Int. Arch. Occup. Environ. Health 2021, 94, 1721-1737. [CrossRef] [PubMed]

53. Gül, Ş.; Kılıç, S.T. Determining Anxiety Levels and Related Factors in Operating Room Nurses during the COVID-19 Pandemic: A Descriptive Study. J. Nurs. Manag. 2021, 29, 1934-1945. [CrossRef] 
54. Havaei, F.; Ma, A.; Staempfli, S.; MacPhee, M. Nurses' Workplace Conditions Impacting Their Mental Health during COVID-19: A Cross-Sectional Survey Study. Healthcare 2021, 9, 84. [CrossRef] [PubMed]

55. Halley, M.C.; Mathews, K.S.; Diamond, L.C.; Linos, E.; Sarkar, U.; Mangurian, C.; Sabry, H.; Goyal, M.K.; Olazo, K.; Miller, E.G.; et al. The Intersection of Work and Home Challenges Faced by Physician Mothers during the Coronavirus Disease 2019 Pandemic: A Mixed-Methods Analysis. J. Women's Health 2021, 30, 514-524. [CrossRef] [PubMed]

56. Hu, J.; He, W.; Zhou, K. The Mind, the Heart, and the Leader in Times of Crisis: How and When COVID-19-Triggered Mortality Salience Relates to State Anxiety, Job Engagement, and Prosocial Behavior. J. Appl. Psychol. 2020, 105, 1218-1233. [CrossRef]

57. Ingusci, E.; Signore, F.; Giancaspro, M.L.; Manuti, A.; Molino, M.; Russo, V.; Zito, M.; Cortese, C.G. Workload, Techno Overload, and Behavioral Stress during COVID-19 Emergency: The Role of Job Crafting in Remote Workers. Front. Psychol. 2021, 12, 655148. [CrossRef] [PubMed]

58. Mekonen, E.; Shetie, B.; Muluneh, N. The Psychological Impact of COVID-19 Outbreak on Nurses Working in the Northwest of Amhara Regional State Referral Hospitals, Northwest Ethiopia. Psychol. Res. Behav. Manag. 2020, 13, 1353-1364. [CrossRef]

59. Al-Jumaili, A.A.; Al-Fatlawi, B.G.; Al-Jalehawi, A.K.; Al-Hamadani, F.Y.; Alsawad, O.S. Impact of COVID-19 Pandemic on Healthcare Providers: Save the Frontline Fighters. Int. J. Pharm. Pract. 2021, 29, riab018. [CrossRef]

60. Mo, Y.; Deng, L.; Zhang, L.; Lang, Q.; Pang, H.; Liao, C.; Wang, N.; Tao, P.; Huang, H. Anxiety of Nurses to Support Wuhan in Fighting against COVID-19 Epidemic and Its Correlation with Work Stress and Self-Efficacy. J. Clin. Nurs. 2021, 30, 397-405. [CrossRef]

61. Nguyen, P.T.L.; Nguyen, T.B.L.; Pham, A.G.; Duong, K.N.C.; Gloria, M.A.J.; Vo, T.V.; Vo, B.V.; Phung, T.L. Psychological Stress Risk Factors, Concerns and Mental Health Support Among Health Care Workers in Vietnam during the Coronavirus Disease 2019 (COVID-19) Outbreak. Front. Public Health 2021, 9, 628341. [CrossRef]

62. Norful, A.A.; Rosenfeld, A.; Schroeder, K.; Travers, J.L.; Aliyu, S. Primary Drivers and Psychological Manifestations of Stress in Frontline Healthcare Workforce during the Initial COVID-19 Outbreak in the United States. Gen. Hosp. Psychiatry 2021, 69, 20-26. [CrossRef] [PubMed]

63. Rodríguez-López, A.M.; Rubio-Valdehita, S.; Díaz-Ramiro, E.M. Influence of the COVID-19 Pandemic on Mental Workload and Burnout of Fashion Retailing Workers in Spain. Int. J. Environ. Res. Public Health 2021, 18, 983. [CrossRef] [PubMed]

64. Tokac, U.; Razon, S. Nursing Professionals' Mental Well-Being and Workplace Impairment during the COVID-19 Crisis: A Network Analysis. J. Nurs. Manag. 2021, 29, 1653-1659. [CrossRef] [PubMed]

65. Coulombe, S.; Pacheco, T.; Cox, E.; Khalil, C.; Doucerain, M.M.; Auger, E.; Meunier, S. Risk and Resilience Factors during the COVID-19 Pandemic: A Snapshot of the Experiences of Canadian Workers Early on in the Crisis. Front. Psychol. 2020, 11, 580702. [CrossRef]

66. Moreno-Jiménez, J.E.; Blanco-Donoso, L.M.; Demerouti, E.; Belda Hofheinz, S.; Chico-Fernández, M.; Moreno-Jiménez, B.; Garrosa, E. The Role of Healthcare Professionals' Passion in Predicting Secondary Traumatic Stress and Posttraumatic Growth in the Face of COVID-19: A Longitudinal Approach. Int. J. Environ. Res. Public Health 2021, 18, 4453. [CrossRef]

67. Zhang, X.; Zhao, K.; Zhang, G.; Feng, R.; Chen, J.; Xu, D.; Liu, X.; Ngoubene-Atioky, A.J.; Huang, H.; Liu, Y.; et al. Occupational Stress and Mental Health: A Comparison Between Frontline Medical Staff and Non-Frontline Medical Staff during the 2019 Novel Coronavirus Disease Outbreak. Front. Psychiatry 2020, 11, 555703. [CrossRef]

68. Aronsson, G.; Theorell, T.; Grape, T.; Hammarström, A.; Hogstedt, C.; Marteinsdottir, I.; Skoog, I.; Träskman-Bendz, L.; Hall, C. A Systematic Review Including Meta-Analysis of Work Environment and Burnout Symptoms. BMC Public Health 2017, 17, 264. [CrossRef] [PubMed]

69. Heath, C.; Sommerfield, A.; von Ungern-Sternberg, B.S. Resilience Strategies to Manage Psychological Distress among Healthcare Workers during the COVID-19 Pandemic: A Narrative Review. Anaesthesia 2020, 75, 1364-1371. [CrossRef] [PubMed]

70. Lecca, L.I.; Finstad, G.L.; Traversini, V.; Lulli, L.G.; Gualco, B.; Taddei, G. The Role of Job Support as a Target for the Management of Work-Related Stress: The State of Art. Qual.-Access Success 2020, 21, 152-158. Available online: https:/ / www.proquest.com/ openview /f7f3198c1fdfd682d43d73503460efc3/1?pq-origsite=gscholar\&cbl=1046413 (accessed on 11 September 2021).

71. Mead, S.; Hilton, D.; Curtis, L. Peer Support: A Theoretical Perspective. Psychiatr. Rehabil. J. 2001, 25, 134-141. [CrossRef] [PubMed]

72. Hancock, F.; Page, F. Family to Work Conflict and the Usefulness of Workplace Support. Occup. Med. 2013, 63, 373-376. [CrossRef] [PubMed]

73. Agarwal, B.; Brooks, S.K.; Greenberg, N. The Role of Peer Support in Managing Occupational Stress: A Qualitative Study of the Sustaining Resilience at Work Intervention. Workplace Health Saf. 2020, 68, 57-64. [CrossRef] [PubMed]

74. Finstad, G.L.; Giorgi, G.; Lulli, L.G.; Pandolfi, C.; Foti, G.; León-Perez, J.M.; Cantero-Sánchez, F.J.; Mucci, N. Resilience, Coping Strategies and Posttraumatic Growth in the Workplace Following COVID-19: A Narrative Review on the Positive Aspects of Trauma. Int. J. Environ. Res. Public Health 2021, 18, 9453. [CrossRef]

75. Banerjee, D.; Sathyanarayana Rao, T.S.; Kallivayalil, R.A.; Javed, A. Psychosocial Framework of Resilience: Navigating Needs and Adversities During the Pandemic, A Qualitative Exploration in the Indian Frontline Physicians. Front. Psychol. $2021,12,622132$. [CrossRef]

76. Windle, G. What Is Resilience? A Review and Concept Analysis. Rev. Clin. Gerontol. 2011, 21, 152-169. [CrossRef]

77. Eisenberger, R.; Huntington, R.; Hutchison, S.; Sowa, D. Perceived Organizational Support. J. Appl. Psychol. 1986, 71, 500-507. Available online: https:/ / doi.apa.org/doiLanding?doi=10.1037\%2F0021-9010.71.3.500 (accessed on 4 September 2021). [CrossRef] 
78. Bowling, N.A.; Alarcon, G.M.; Bragg, C.B.; Hartman, M.J. A Meta-Analytic Examination of the Potential Correlates and Consequences of Workload. Work Stress 2015, 29, 95-113. [CrossRef]

79. Sommerville, K.L. Hospitality Employee Management and Supervision: Concepts and Practical Applications; John Wiley \& Sons, Inc.: Hoboken, NJ, USA, 2007; ISBN 978-0-470-07427-5.

80. Saedpanah, D.; Salehi, S.; Moghaddam, L.F. The Effect of Emotion Regulation Training on Occupational Stress of Critical Care Nurses. J. Clin. Diagn. Res. 2016, 10, VC01-VC04. [CrossRef] [PubMed]

81. Eilström, P.-E.; Kock, H. Competence Development in the Workplace: Concepts, Strategies and Effects. Asia Pac. Educ. Rev. 2008, 9, 5-20. [CrossRef]

82. Bakker, A.B.; Demerouti, E. Job Demands-Resources Theory: Taking Stock and Looking Forward. J. Occup. Health Psychol. 2017, 22, 273-285. [CrossRef]

83. Hall, L.H.; Johnson, J.; Watt, I.; Tsipa, A.; O'Connor, D.B. Healthcare Staff Wellbeing, Burnout, and Patient Safety: A Systematic Review. PLoS ONE 2016, 11, e0159015. [CrossRef]

84. Lee, D.-J.; Sirgy, M.J. What Do People Do to Achieve Work-Life Balance? A Formative Conceptualization to Help Develop a Metric for Large-Scale Quality-of-Life Surveys. Soc. Indic. Res. 2018, 138, 771-791. [CrossRef]

85. Fuß, I.; Nübling, M.; Hasselhorn, H.M.; Schwappach, D.; Rieger, M.A. Working Conditions and Work-Family Conflict in German Hospital Physicians: Psychosocial and Organisational Predictors and Consequences. BMC Public Health $2008,8,353$. Available online: https:/ /bmcpublichealth.biomedcentral.com/articles/10.1186/1471-2458-8-353 (accessed on 6 September 2021). [CrossRef] [PubMed]

86. Langballe, E.M.; Innstrand, S.T.; Aasland, O.G.; Falkum, E. The Predictive Value of Individual Factors, Work-Related Factors, and Work-Home Interaction on Burnout in Female and Male Physicians: A Longitudinal Study. Stress Health 2011, $27,73-87$. [CrossRef]

87. Sorrentino, E.; Vona, R.; Monterosso, D.; Giammarioli, A.M. Gender Issues on Occupational Safety and Health. Ann. Ist. Super. Sanità 2016, 52, 190-197. [CrossRef]

88. La Torre, G.; De Leonardis, V.; Chiappetta, M. Technostress: How Does It Affect the Productivity and Life of an Individual? Results of an Observational Study. Public Health 2020, 189, 60-65. Available online: https://reader.elsevier.com/reader/sd/pii/ S0033350620304200?token=FD099DCCC7326E6FD013476B82EAA4877C33816CB9D99182CC98E4849003A9BFA3F3E6799384 1D3B2184E8D43EB2C330\&originRegion=eu-west-1\&originCreation=20210904130142 (accessed on 4 September 2021). [CrossRef] [PubMed]

89. Ragu-Nathan, T.S.; Tarafdar, M.; Ragu-Nathan, B.S.; Tu, Q. The Consequences of Technostress for End Users in Organizations: Conceptual Development and Empirical Validation. Inf. Syst. Res. 2008, 19, 417-433. [CrossRef]

90. Day, A.; Paquet, S.; Scott, N.; Hambley, L. Perceived Information and Communication Technology (ICT) Demands on Employee Outcomes: The Moderating Effect of Organizational ICT Support. J. Occup. Health Psychol. 2012, 17, 473-491. [CrossRef] [PubMed]

91. Basyouni, S.S.; El Keshky, M.E.S. Job Insecurity, Work-Related Flow, and Financial Anxiety in the Midst of COVID-19 Pandemic and Economic Downturn. Front. Psychol. 2021, 12, 2681. [CrossRef] [PubMed] 